NBER WORKING PAPER SERIES

\title{
A SOLUTION TO FISCAL PROCYCLICALITY: THE STRUCTURAL BUDGET INSTITUTIONS PIONEERED BY CHILE
}

\author{
Jeffrey A. Frankel \\ Working Paper 16945 \\ http://www.nber.org/papers/w16945
NATIONAL BUREAU OF ECONOMIC RESEARCH
1050 Massachusetts Avenue
Cambridge, MA 02138
April 2011

This paper was presented at the 14th Annual Conference of the Central Bank of Chile, Oct. 2010, Santiago. The author wishes to thank Jesse Schreger for exceptional research assistance. He would also like to thank Roel Beetsma, Carlos Alvarado, Mauricio Calani, Mauricio Cardenas, Luis Céspedes, Massimo Giuliodori, Martin Mühleisen, Claudia Bulos Ramirez, and Victoria Rodriguez for help acquiring data; Philippe Bacchetta, Roel Beetsma, Cynthia Balloch, Sebastian Bustos, Philippe Martin, Guillermo Perry, Klaus Schmidt-Hebbel, and Andrés Velasco for comments; and the Weatherhead Center for International Affairs at Harvard for support. The January 2011 version of this paper appears as Central Bank of Chile Working Paper 604 and Harvard CID Working Paper 216. The present version adds country fixed effects to the estimation, as did HKS Working Paper 11-012, and condenses results to save space. It is forthcoming in Fiscal Policy and Macroeconomic Performance, edited by Luis Felipe Céspedes and Jordi Galí, Series on Central Banking, Analysis, and Economic Policies, Central Bank of Chile, Nov. 2011. The views expressed herein are those of the author and do not necessarily reflect the views of the National Bureau of Economic Research.

NBER working papers are circulated for discussion and comment purposes. They have not been peerreviewed or been subject to the review by the NBER Board of Directors that accompanies official NBER publications.

(C) 2011 by Jeffrey A. Frankel. All rights reserved. Short sections of text, not to exceed two paragraphs, may be quoted without explicit permission provided that full credit, including $\odot$ notice, is given to the source. 
A Solution to Fiscal Procyclicality: The Structural Budget Institutions Pioneered by Chile Jeffrey A. Frankel

NBER Working Paper No. 16945

April 2011

JEL No. E62,F41,H50,O54,Q33

\begin{abstract}
Historically, many countries have suffered a pattern of procyclical fiscal policy: spending too much in booms and then forced to cut back in recessions. This problem has especially plagued Latin American commodity exporters. Since 2000, fiscal policy in Chile has been governed by a structural budget rule that has succeeded in implementing countercyclical fiscal policy. Official estimates of trend output and the 10-year price of copper - which are key to the decomposition of the budget into structural versus cyclical components - are made by expert panels and thus insulated from the political process. Chile's fiscal institutions hold useful lessons everywhere, but especially in other commodity exporting countries.
\end{abstract}

This paper finds statistical support for a series of hypotheses regarding forecasts by official agencies that have responsibility for formulating the budget.

1)ШOfficial forecasts of budgets and GDP in a 33-country sample are overly optimistic on average.

2)ШThe bias is stronger at longer horizons

3)ШThe bias is greater among European governments that are politically subject to the budget rules

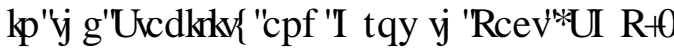

4)ШThe bias is greater in booms.

5)Шn most countries, the real growth rate is the key macroeconomic input for budget forecasting. , QR\&KIOIIWWULXHSUFHRIIFRSSHU

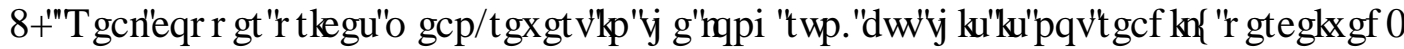

7)凹Chile has avoided the problem of overly optimistic official forecasts.

The conclusion: official forecasts tend to be overly optimistic, if not insulated from politics, and the problem can be worse when the government is formally subject to budget rules. The key innovation that has allowed Chile to achieve countercyclical fiscal policy in general, and to run surpluses in booms in particular, is not just a structural budget rule in itself, but a regime that entrusts to independent expert panels responsibility for estimating long-run trends in copper prices and GDP.

Jeffrey A. Frankel

Kennedy School of Government

Harvard University

79 JFK Street

Cambridge, MA 02138

and NBER

jeffrey_frankel@harvard.edu 


\section{A Solution to Fiscal Procyclicality: The Structural Budget Institutions Pioneered by Chile \\ Outline}

Introduction

1) Chile's fiscal institutions

a) Targeting the structural budget balance, to allow some cyclical flexibility

b) Chile's definition of structural balance

c) The first decade of experience with Chile's structural budget regime

2) Volatility among commodity exporters

a) The procyclicality of capital flows to developing countries

b) The procyclicality of fiscal policy

3) The problem of procyclical fiscal policy among mineral exporters
a) Commodity cycles and the budget
b) Reasons for overshooting in mineral prices
c) Evidence of reversion to long run equilibrium in real copper prices
d) Private forecasts of copper prices

4) Econometric test of over-optimism in government forecasts
a) Are official budget forecasts overly optimistic on average?
b) Are official growth forecasts overly optimistic on average?
c) The influence of macroeconomic fluctuations on budget balances
d) Are official budget forecasts more prone to over-optimism in booms?
e) Are official budget forecasts more prone to over-optimism when the country is subject to a budget rule?
f) Is over-optimism in growth forecasts worse in booms?
g) Are official forecasts over-optimistic at cyclical lows as well as highs?
h) Summary of statistical findings

5) Countercyclical fiscal institutions generalized for other countries

6) Concluding thoughts

7) References

8) Appendices 


\section{Introduction}

In June 2008, the President of Chile, Michele Bachelet, had a low approval rating, especially for management of the economy. There were undoubtedly multiple reasons for this, but one was popular resentment that the government had resisted intense pressure to spend the soaring receipts from copper exports. Copper is Chile's biggest export, and Chile is the world's biggest copper exporter. The world price of copper was at $\$ 800$ per metric ton in 2008, an historic high in nominal terms and more than quadruple the level of 2001. Yet the government insisted on saving most of the proceeds.

One year later, in mid-2009, Bachelet had attained the highest approval rating of any President since democracy had returned to Chile (shown in Figure $1^{1}$ ). She kept it through the remainder of her term. At the same time, her Finance Minister, Andrés Velasco, also had the highest approval rating of any Finance Minister since the restoration of democracy (Figure 2). Why the change? Not an improvement in overall economic circumstances. In the meantime the global recession had hit. Copper prices had fallen, as shown in Figure 3, and growth had declined as well. But the government had increased spending sharply, using the assets that it had acquired during the copper boom, and had thereby moderated the downturn. Saving for a rainy day made the officials heroes, now that the rainy day had come.

Thus Chile has over the last decade achieved what few commodity-producing developing countries had previously achieved: a truly countercyclical fiscal policy. It has beaten the curse of procyclicality via the innovation of a set of fiscal institutions that are designed to work even in a world where politicians and voters are fallible human beings rather than angels.

The proposition that institutions make a big difference, that good policies are less likely in the absence of good institutions, has popped up everywhere in economics in recent years. ${ }^{2}$ What is sometimes missing is specific examples of institutions that effectively balance constraints with flexibility. Even though specifics differ from country to country, Chile's institutions are an interesting example that other countries, particularly those with significant natural resources, could consider trying to emulate. ${ }^{3}$ Even advanced countries and non-commodity-producers, for that matter, could take a page from the Chilean book. Proper budget discipline is easy nowhere, and commodity cycles are but one kind of cyclicality that such institutions could address.

\footnotetext{
${ }^{1}$ Ratings for all four presidents since 1991 are illustrated in Figure $1 \mathrm{~b}$ of the January 2011 working paper. These graphs are taken from Engel, Neilson and Valdez (2011).

${ }^{2}$ In the case of fiscal policy, the importance of institutions has been emphasized by Buchanan (1967), von Hagen and Harden (1995), Alesina and Perotti (1995, 1996), Poterba (1997), Poterba and von Hagen (1999), Persson and Tabellini (2004), Wyplosz (2005), Calderón and Schmidt-Hebbel (2008), and Calderón, Duncan and Schmidt-Hebbel (2010). For commodity-producers more specifically: Davis et al (2001, 2003) and Ossowski, et al (2008), among others. For Latin America: Alesina, Hausmann, Hommes, and Stein (1999), Stein, Talvi, and Grisanti (1999), and Perry (2003), among others

3 The structural budget regime is of course but one of many innovative reforms that Chile has adopted over the last few decades, many of which have been successful. Corbo and Fischer (1994), Edwards and Edwards (1991, 2000), Ffrench-Davis (2010), and Velasco (1994).
} 
Figure 1: Approval of president and economic management under two Chilean administrations

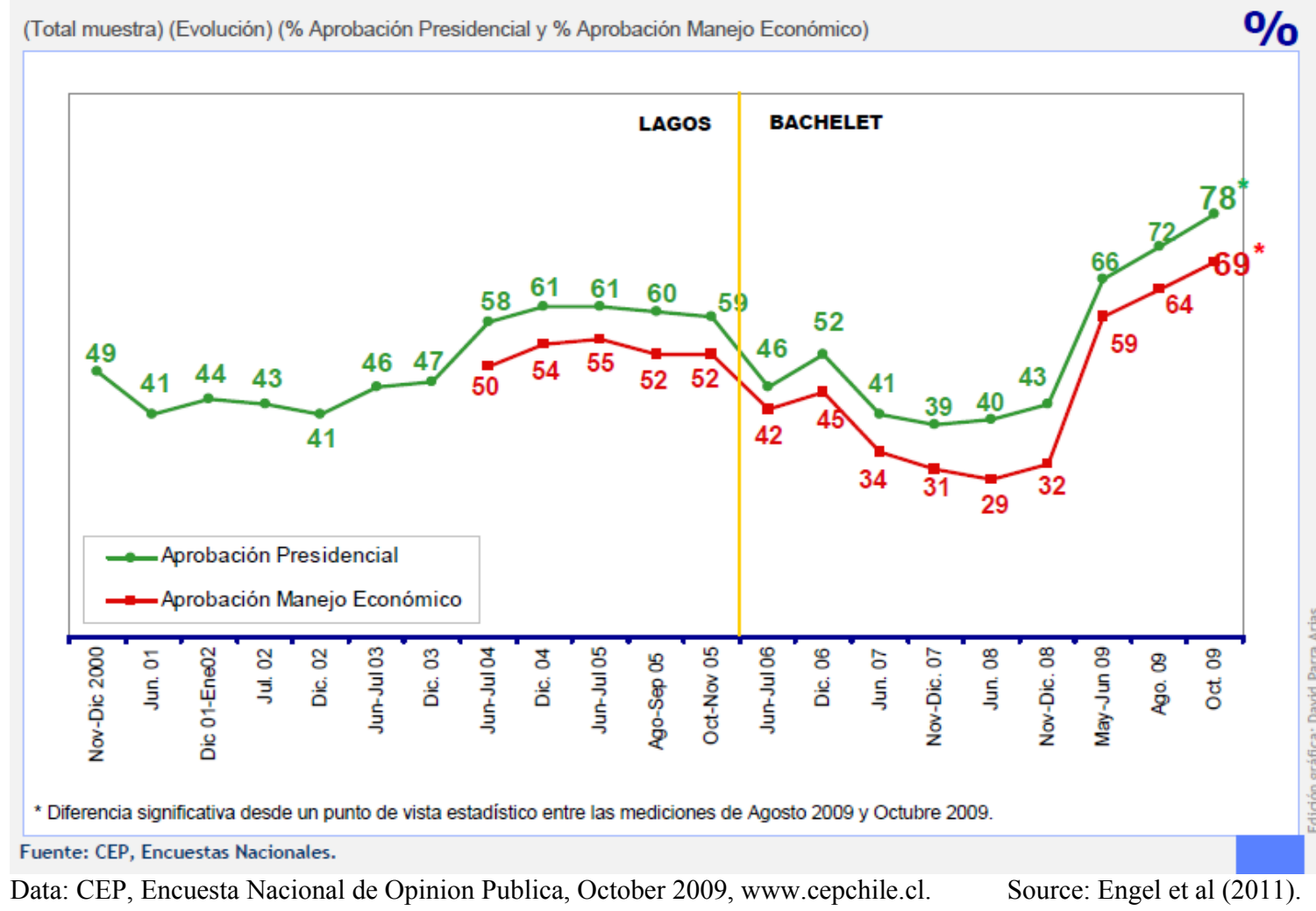

Figure 2: Ratings of political figures in 2009, including Presidents and Ministers (Rating is evaluation of political personalities among those familiar with the person.*) (Total muestra)

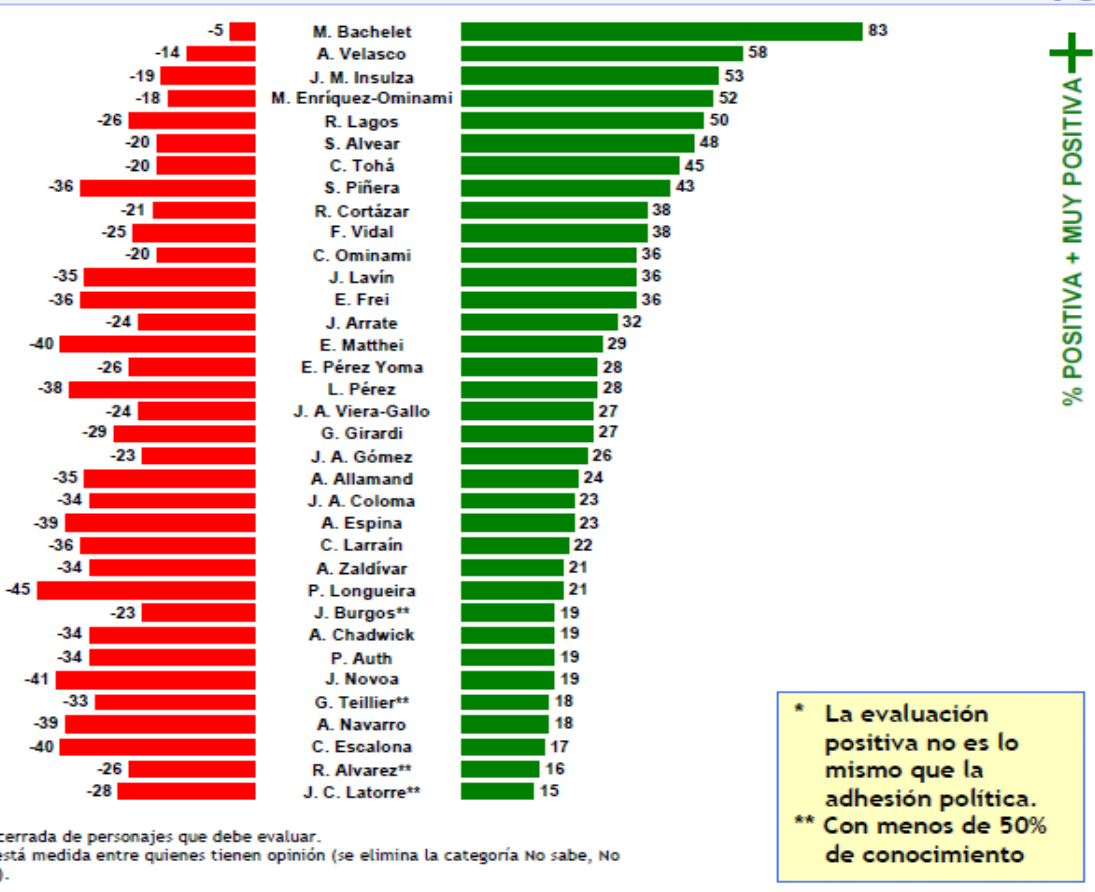

Nota 1: Al entrevistado se le lee una lista cerrada de personajes que debe evaluar.

Nota 2: La evaluación positiva y negativa está medida entre quienes tienen opinión (se elimina la categoría No sabe, No contesta y No conoce a la persona).

Data: CEP, Encuesta Nacional de Opinion Publica, October 2009, www.cepchile.cl.

Source: Engel et al (2011). 


\section{Chile's fiscal institutions}

Looking at the budget balance in structural or cyclically adjusted terms is of course an old idea. We mean something more when we refer to Chile's structural budget regime.

Chile's fiscal policy is governed by a set of rules. The first rule is that the government must set a budget target. The target was originally set at a surplus of $1 \%$ of GDP, for three reasons: (i) recapitalizing the central bank, which inherited a negative net worth from bailing out the private banking system in the 1980s and some sterilization of inflows in the 1990s, (ii) funding some pension-related and other liabilities, and (iii) servicing net external dollar debt. ${ }^{4}$ The target was subsequently lowered to $1 / 2 \%$ of GDP in 2007, and again to 0 in 2009, as it was determined that the debt had been essentially paid off and that a structurally balanced budget was economically appropriate. ${ }^{5}$

\section{Targeting the structural budget balance, to allow some cyclical flexibility}

A budget target of zero may sound similar to the budget deficit ceilings that supposedly constrain members of Euroland (deficits of $3 \%$ of GDP under the Stability and Growth Pact) or to U.S. proposals for a Balanced Budget Amendment (zero deficit). But those attempts have failed, in part because they are too rigid to allow the need for deficits in recessions, counterbalanced by surpluses in good times.

It is not always the case that "tougher" constraints on fiscal policy increase effective budget discipline. Countries often violate their constraints. In an extreme setup, a rule that is too rigid -- so rigid that official claims that it will be sustained are not credible -- might even lead to looser fiscal outcomes than if a more moderate and flexible rule had been specified at the outset. ${ }^{6}$

Certainly euro countries large and small have repeatedly violated the fiscal rules of the Stability and Growth Pact, originally a simple ceiling on the budget deficit of 3\% of GDP. However, the SGP lacks a credible enforcement mechanism. The main idea that Brussels has had for enforcement is to fine governments that are unable to maintain the targets. In actuality many governments, of countries large and small, have not maintained the targets and have not been penalized for doing so. ${ }^{7}$

Credibility can be a problem for budget institutions either with or without uncertainty regarding the future path of the economy. Consider first the nonstochastic case. Even in cases where the future proceeds as expected when the rule was formulated, the target may be up against predictably irresistible political pressures. Common examples are provisions for Special Fiscal Institutions that may have been written out to please the World Bank or IMF, but without local elites "taking ownership" of the

\footnotetext{
${ }^{4}$ Rodríguez, Tokman and Vega (2007, p.5, 21).

5 A team of three economists appointed by Velasco recommended reducing the structural budget target: Engel, Marcel and Meller (2007). Sources: Velasco, Céspedes, Rodríguez Cabello, and Arenas de Mesa (2007), Velasco, Arenas, Rodríguez, Jorratt de Luis, Gamboni (2010); and "The options that the Treasury had to relax the rule," El Mercurio, Chile, May 24, 2007.

${ }^{6}$ Neut and Velasco (2003).

${ }^{7}$ The fine is not a credible penalty, because a government that hasn't been able to raise enough tax revenue to finance its level of spending is not likely to be able to come up with even more revenue to pay the fine.
} 
reforms, let alone winning public support for them. Such institutions, which include fiscal rules and fiscal responsibility legislation, are often abandoned before long. ${ }^{8}$

The case of rules that are too onerous to last arises particularly in the stochastic context. A target that might have been reasonable ex ante, such as an unconditionally balanced budget, becomes unreasonable after an unexpected shock, such as a severe fall in export prices or national output. Common examples are rigid balanced budget rules that do not allow for the possibility of fiscal deficits in bad times.

A sensible alternative is to specify rules that mandate changes in response to changed circumstances. In particular, instead of targeting an actual budget balance of zero, or some other numerical surplus, the rule can target a number for the structural budget.

This alternative may not work, however, if the political process determines whether a deficit is or is not structural. It does not necessarily succeed in imposing discipline. Politicians can always attribute a budget deficit to unexpectedly and temporarily poor economic growth. Since there is no way of proving what an unbiased forecast of growth is, there is no way of disproving the politicians' claim that the shortfall is not their responsibility.

\section{Chile's definition of structural balance}

Copper accounts for approximately $16 \%$ of Chile's fiscal income: about $10 \%$ from the revenues of CODELCO, which is owned by the government, and the rest in tax revenue from private mining companies. ${ }^{9}$ That the figure is only $16 \%$ illustrates that Chile's use of copper exports has not prevented it from achieving a diversified economy. Having said that, the number understates the sensitivity of the budget to copper prices. Copper profits are highly volatile, more volatile even than copper prices because of fixed costs in production. Furthermore the mining industry tends to have a multiplier effect on the rest of GDP. Madrid-Aris and Villena (2005) argue that copper prices drive the Chilean economy. ${ }^{10}$ Other mineral and agricultural commodities are important as well, though their prices on world markets are to some extent correlated with copper. ${ }^{11}$

The central rule that makes up Chile's structural balance regime is that the government can run a deficit larger than the target to the extent that:

(1) output falls short of its long-run trend, in a recession, or

\footnotetext{
${ }^{8}$ An econometric analysis of these Special Financial Institutions for oil-producers by Ossowski, et al (2008, pp. 19, 23, 24, 38-43) finds no statistically significant effect on the actual fiscal stance. This may be partly due to econometric limitations. But it is evidently also in part due to governments that, after having adopted these institutions, subsequently find them too rigid in practice and so weaken or abandon them. Recent examples include Ecuador, Equatorial Guinea, and Venezuela (pp. 12-13, 19, 24). Also Villafuerte et al (2010).

9 Rodriguez (2007, p. 8).

10 Their econometrics are cointegration tests and their theory is essentially classic Dutch Disease: an increase in copper prices is transmitted to the non-tradable sector via appreciation of the currency.

11 Nitrates were the important export before World War I. Fruits and wines have gained importance in recent years. Larrain, Sachs and Warner (2000) discuss the reasons for Chile's heavy structural dependence on commodity exports, which they view as negative for long-term growth. The reasons include not just natural endowments, but also a small internal market and geographic remoteness which necessitate exports that have a high ratio of value added to transport cost.
} 
(2) the price of copper is below its medium-term (10-year) equilibrium.

The key institutional innovation is that there are two panels of experts whose job it is each mid-year to make the judgments regarding the output gap and the medium term equilibrium price of copper. The experts on the copper panel are drawn from mining companies, the financial sector, research centers, and universities. The government then follows a set of procedures that translates these numbers, combined with any given set of tax and spending parameters, into the estimated structural budget balance. If the resulting estimated structural budget balance differs from the target, then the government adjusts spending plans until the desired balance is achieved.

\section{The first decade of experience with Chile's structural budget regime}

Already by 2006 the structural budget policy had shown clear benefits. Between 2000 and 2005 , public savings rose from $2.5 \%$ of GDP to $7.9 \%$ (allowing national saving to rise from $20.6 \%$ to $23.6 \%$ ). ${ }^{12}$ As a result, central government debt fell sharply as a share of GDP and the sovereign spread gradually declined. ${ }^{13}$ By December 2006, Chile had achieved a sovereign debt rating of A, several notches ahead of Mexico, Brazil, and other Latin American peers. ${ }^{14}$ By 2007 Chile had become a net creditor. By June 2010, its sovereign rating had climbed to $\mathrm{A}^{+}$, ahead of some richer countries: Israel and Korea (A), let alone Iceland (BBB-) or Greece (BB+).

The announcement of the structural surplus rule in itself appears to have improved Chile's creditworthiness in 2000, even before it had had time to operate. ${ }^{15}$ Even this early, better access to foreign capital may have helped the country to weather the 2001-02 crisis more easily than the crisis of 1982-83. ${ }^{16}$ Public spending fluctuated much less than in past decades, and less than income, ${ }^{17}$ helping to stabilize the business cycle. According to one estimate, the structural balance policy allowed a reduction in GDP volatility of $1 / 3$ in 2001-05. ${ }^{18}$ Another study goes so far as to claim that the policy can all-but-eliminate the effects of copper price fluctuations on the real economy. ${ }^{19}$

The real test of the policy came during the latter years of the copper boom of 2003-2008 with strong political pressure to declare the increase in the price of copper permanent thereby justifying increased spending on a par with export earnings. The expert panel ruled that most of the price increase was temporary so that most of the earnings had to be saved. This turned out to be right, as the 2008 spike indeed partly reversed the next year. As a result, the fiscal surplus reached almost $9 \%$ when copper

\footnotetext{
12 Rodríguez, Tokman and Vega (2007, p.27).

${ }^{13}$ Ibid. (p.29-30).

14 Standard and Poor ratings, obtained from Bloomberg.

${ }^{15}$ Lefort (2006) substantiates empirically that the structural balance rule made a significant contribution in reducing the country risk margin beyond the effect of lower public indebtedness. Rodríguez, Tokman and Vega (2007, p.30) report a turnaround in Chile's sovereign spread from the date of the announcement in early 2000. Perry $(2003,13-14)$ also sees an immediate credibility effect .

${ }^{16}$ Rodríguez, Tokman and Vega (2007, p.32). The external shocks in 1982 were a recession in advanced countries and the international debt crisis. The external shocks in 2001 were another (admittedly milder) US recession and a debt crisis next door in Argentina.

${ }^{17}$ Rodríguez, Tokman and Vega (2007, p.33-34).

${ }^{18}$ Larrain and Parro (2006).

${ }^{19}$ Medina and Soto (2007) find in a DSGE model that the fiscal regime is capable of reducing the effect on Chile's GDP of a $10 \%$ exogenous increase in the copper price from $0.70 \%$ to $0.05 \%$.
} 
prices were high. The country paid down its debt to a mere $4 \%$ of GDP and it saved about $12 \%$ of GDP in the sovereign wealth fund. This allowed a substantial fiscal easing in the recession of 2008-09, when the stimulus was most sorely needed.

Figure 3: The real price of copper over 50 years

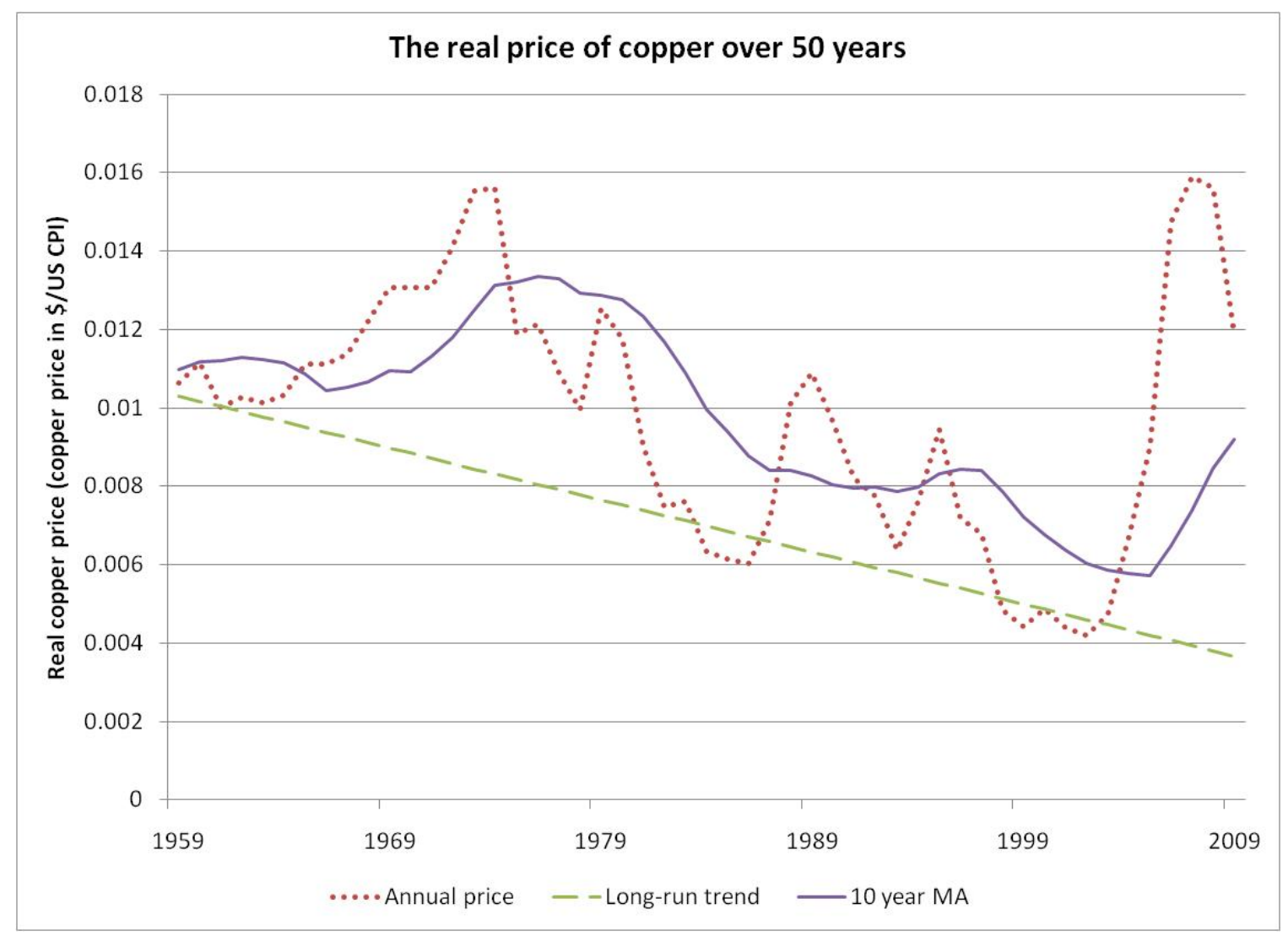


Part of the credit for Chile's structural budget rule should go to the preceding government of President Ricardo Lagos (2000-2006) and Finance Minister Nicolas Eyzaguirre. They initiated the structural budget criterion and the panels of experts. ${ }^{20}$ But in this first phase, the budget rule was a policy initiated and followed voluntarily by the government, rather than a matter of legal or other constraint. ${ }^{21}$ The structural budget rule became a true institution under the Bachelet government (2006-2010), which enshrined the general framework in law. It introduced a Fiscal Responsibility Bill in 2006, which gave legal force to the role of the structural budget. ${ }^{22}$ Just as important, it abided by the law when it was most difficult to do so politically. In fact the Bachelet government took extra steps to make sure the copper bonanza was saved in 2006-08, beyond the requirements of the law, which allowed extra easing in 2009-10. (One might say that the Chilean law requires only that fiscal policy be acyclical - with the government passively spending only its long-term income and saving only the cyclical component - and that the government went beyond this and undertook an active countercyclical policy on a discretionary basis. ${ }^{23}$ ) The public approbation received by the Bachelet government in the polls by the end of its term in office was in this sense well-earned.

The advice to save in a boom is standard. And there are other examples of governments that have had the courage to take away the fiscal punch bowl. What makes Chile's institutions particularly worthy of study is that they may constitute a template that other countries can adopt, a model that can help even in times and places where the political forces to follow procyclical fiscal policy would otherwise be too strong to resist.

Section 2 highlights economic volatility among countries that are dependent on exports of mineral and agricultural products. Section 3 focuses on procyclical fiscal policy is among commodity producers. We then turn to the role played by systematic bias in official budget forecasts in other countries, and how Chile has avoided it.

\section{Volatility among commodity exporters}

The economies of developing countries tend to be more volatile generally than those of advanced countries. The volatility arises in part from foreign shocks, such as fluctuations in the prices of exports on world markets, which are particularly large for mineral and agricultural commodities produced by Latin American countries, as Table 1

\footnotetext{
${ }^{20}$ Page 11 of International Monetary Fund, Chile 2005 Article IV Consultation, IMF Country Report 05/013 (September 2005). Some credit should also go to earlier governments, for the establishment of the Copper Stabilization Fund in the 1980s, which stipulated that copper revenue above a certain price was to be saved, and for sticking with the rule when the price rose later.

${ }^{21}$ Aninat, Landregan, Navia, and Vial (2006, p.8, 54); Rodríguez, Tokman and Vega (2007, p.5).

22 The bill, Law No. 20.128, was proposed by the government in September 2005 and approved by Congress to go into effect in August 2006. Among other things it also created a Pension Reserve Fund and a Social and Economic Stabilization Fund, the latter a replacement for the existing Copper Stabilization Funds that dated from 1981, and specified norms for how the Funds should be invested.

${ }^{23}$ This terminological question is not new: do automatic stabilizers constitute countercyclical fiscal policy? This paper calls the budget rule countercyclical because the contrast is so strong with the procyclical fiscal policies of so many other countries, especially commodity producers. More important than the terminological question is the substantive one: is there some way of building into the fiscal institution an extra degree of countercyclicality in order to dampen the business cycle, without relying on the discretion of the government?
} 
shows. ${ }^{24}$ But volatility also arises in part from domestic macroeconomic and political instability. ${ }^{25}$ Although in the 1990s most developing countries brought the chronic runaway budget deficits, money creation, and inflation that they experienced in the preceding two decades under control, most are still subject to monetary and fiscal policy that is procyclical rather than countercyclical: they tend to be expansionary in booms and contractionary in recessions, thereby exacerbating the magnitudes of the swings. The models and textbooks of the decades following the Great Depression originally hoped for the opposite, of course: that discretionary policy would be countercyclical and thereby moderate the swings.

Table 1: Price Volatility of Leading Commodity Exports of Countries in Latin American and the Caribbean

\begin{tabular}{|l|cc|}
\hline & Leading & \multicolumn{2}{|c|}{$\begin{array}{c}\text { Standard Deviation of } \\
\text { Log of Dollar Price }\end{array}$} & 1970-2008 \\
\hline ARG & Commodity Export* & 0.278 \\
BOL & Soybeans & 1.816 \\
BRA & Natural Gas & 0.590 \\
CHL & Steel & 0.408 \\
COL & Copper & 0.759 \\
CRI & Oil & 0.4412 \\
ECU & Bananas & 0.759 \\
GTM & Oil & 0.479 \\
GUY & Coffee & 0.4745 \\
HND & Sugar & 0.479 \\
JAM & Coffee & 0.418 \\
MEX & Aluminum & 0.759 \\
NIC & Oil & 0.479 \\
PAN & Coffee & 0.442 \\
PER & Bananas & 0.408 \\
PRY & Copper & 0.230 \\
SLV & Beef & 0.479 \\
TTO & Coffee & 1.816 \\
URY & Natural Gas & 0.230 \\
VEN & Beef & 0.759 \\
\hline
\end{tabular}

That developing countries tend to experience larger cyclical fluctuations than industrialized countries is only partly attributable to commodities. It is also in part due to the role of factors that "should" moderate the cycle, but in practice seldom operate that way: procyclical capital flows, procyclical monetary and fiscal policy, and the related Dutch Disease. If anything, they tend to exacerbate booms and busts instead of moderating them. The hope that improved policies or institutions might reduce this

${ }^{24}$ Some have suggested that the volatility of natural resource prices in itself is bad for economic growth, the source of the natural resource curse: Blattman, Hwang, and Williamson (2007), Hausmann and Rigobon (2003) and Poelhekke and van der Ploeg (2007).

${ }^{25}$ Perry (2009) decomposes the extra growth volatility. 
procyclicality makes this one of the most potentially fruitful avenues of research in emerging market macroeconomics.

\section{The procyclicality of capital flows to developing countries}

According to the theory of intertemporal optimization, countries borrow internationally during temporary downturns, to sustain consumption and investment, and repay or accumulate net foreign assets during temporary upturns. In practice, it does not always work this way. Capital flows are more often procyclical than countercyclical. ${ }^{26}$ Most theories to explain this involve imperfections in capital markets, such as asymmetric information or the need for collateral. In the commodity and emerging market boom of 2003-2008, net capital flows typically went to countries with trade surpluses, especially Asians and commodity producers in the Middle East and Latin America, where they showed up in record accumulation of foreign exchange reserves. This was in contrast to the two previous cycles, 1975-1981 and 1990-97, when capital flows to developing countries largely went to finance current account deficits.

One interpretation of procyclical capital flows is that they result from procyclical fiscal policy: when governments increase spending in booms, some of the deficit is financed by borrowing from abroad. When they are forced to cut spending in downturns, it is to repay some of the excessive debt that they incurred during the upturn. Another interpretation of procyclical capital flows to developing countries is that they pertain especially to exporters of agricultural and mineral commodities, particularly oil.

\section{The procyclicality of fiscal policy}

Many authors have documented that fiscal policy tends to be procyclical in developing countries, especially in comparison with industrialized countries. ${ }^{27}$ Most studies look at the procyclicality of government spending, because tax receipts are particularly endogenous with respect to the business cycle. An important reason for procyclical spending is precisely that government receipts from taxes or royalties rise in booms, and the government cannot resist the temptation or political pressure to increase spending proportionately, or more than proportionately.

Procyclicality is especially pronounced in countries that possess natural resources and where income from those resources tends to dominate the business cycle. Among those focusing on the correlation between commodity booms and spending booms is Cuddington (1989). Sinnott (2009) finds that Latin American countries are sufficiently commodity-dependent that government revenue responds significantly to commodity prices. $^{28}$

Two large budget items that account for much of the increased spending from commodity booms are investment projects and the government wage bill. Regarding

\footnotetext{
${ }^{26}$ Kaminsky, Reinhart, and Vegh (2005); Reinhart and Reinhart (2009); Gavin, Hausmann, Perotti and Talvi (1996); and Mendoza and Terrones (2008). Caballero (2002) and Gallego, Hernández, and SchmidtHebbel (2002) examine procyclical capital flows in Chile in particular.

27 Cuddington (1989), Tornell and Lane (1999), Kaminsky, Reinhart, and Vegh (2004), Talvi and Végh (2005), Alesina, Campante and Tabellini (2008), Mendoza and Oviedo (2006), Ilzetski and Vegh (2008) and Medas and Zakharova (2009). For Latin America in particular: Gavin and Perotti (1997), Calderón and Schmidt-Hebbel (2003), and Perry (2003).

${ }_{28}$ Arezki and Brückner (2010a, b) examine differences in overspending in autocratic commodity producers versus democratic ones.
} 
the first budget item, investment in infrastructure can have a large long-term pay-off if it is well designed; too often in practice, however, it takes the form of white elephant projects, which are stranded without funds for completion or maintenance, when the commodity price goes back down (Gelb, 1986). Regarding the second budget item, Medas and Zakharova (2009) point out that oil windfalls have often been spent on higher public sector wages. They can also go to increasing the number of workers employed by the government. Either way, they raise the total public sector wage bill, which is hard to reverse when oil prices go back down. ${ }^{29}$

\section{The problem of procyclical fiscal policy among commodity exporters}

Macroeconomic textbooks explain the dangers of discretionary fiscal policy ("fine tuning"), which can offset the stabilizing advantages of countercyclical government budgets. But arguments against ambitious attempts at countercyclical policy are not arguments in favor of procyclical policy. Procyclicality has been the common pattern among developing countries in the past.

\section{Commodity cycles and the budget}

The tendency to undersave in a boom is particularly strong when the country is a commodity producer and the boom originates in high world prices for the commodity in question. ${ }^{30}$ The temptation to spend the windfall is often irresistible. When the commodity prices eventually go back down, countries are often left with high debt, a swollen government sector and non-tradable sector, and hollowed out non-commodity tradable goods sector. They may then be forced to cut back on government spending, completing the perverse cycle of countercyclical saving.

Thus some of the most important ways for countries to cope with the commodity cycle are institutions to insure that export earnings are put aside during the boom time, into a commodity saving fund, perhaps with the aid of rules governing the cyclically adjusted budget surplus. ${ }^{31}$ To design the right institutions, it would help to figure out the reason for the past pattern of procyclicality.

One possibility is that the political process overrides sober judgments, so that spending responds to booms more than intertemporal optimization would dictate, perhaps because the interests of government officials diverge from the public interest. Another possibility is that there is an error in perceptions: forecasters extrapolate a high world price today, during the boom, indefinitely far into the future, whereas in reality the real price will eventually return to some long-run equilibrium.

We can consider the example of copper prices in Chile to illustrate how important commodity price movements are to the task of forecasting the budget. There are several

\footnotetext{
${ }^{29}$ Arezki and Ismail (2010) find that current government spending increases in boom times, but is downward-sticky.

30 They may also undersave on average, of course. Few countries in practice follow the "Hartwick rule," which would have all rents from exhaustible natural resources invested in reproducible capital, so that future generations do not suffer a diminution in total wealth (natural resource plus reproducible capital) and therefore in the flow of consumption. Hartwick (1977) and Solow (1986).

${ }^{31}$ Davis et al (2001a,b, 2003).
} 
ways we can measure the benchmark relative to which the ex post spot price of copper is observed. One is the forward or futures price of copper observed the preceding year. We find that the copper price is indeed a powerful determinant of the budget. Figure 4 plots the official budget forecast error (one year ahead) against the copper price relative to the previous August's forward price. There is clearly a strong relationship. ${ }^{32}$ Table 2 reports the corresponding regression. The copper price is statistically significant and dominates movement in the budget to such an extent that GDP is not significant alongside it. Presumably this reflects not just the important role of copper royalties in Chile's budget revenues, but also the big influence of copper prices on the rest of the economy.

In any case, the bottom line is that anyone who wishes to make unbiased forecasts of next year's budget in Chile needs to be able to make unbiased forecasts of next year's copper price. Thus we turn next to the question of the copper price's time series behavior.

Figure 4: Short-term influence of copper price movements on Chile's budget

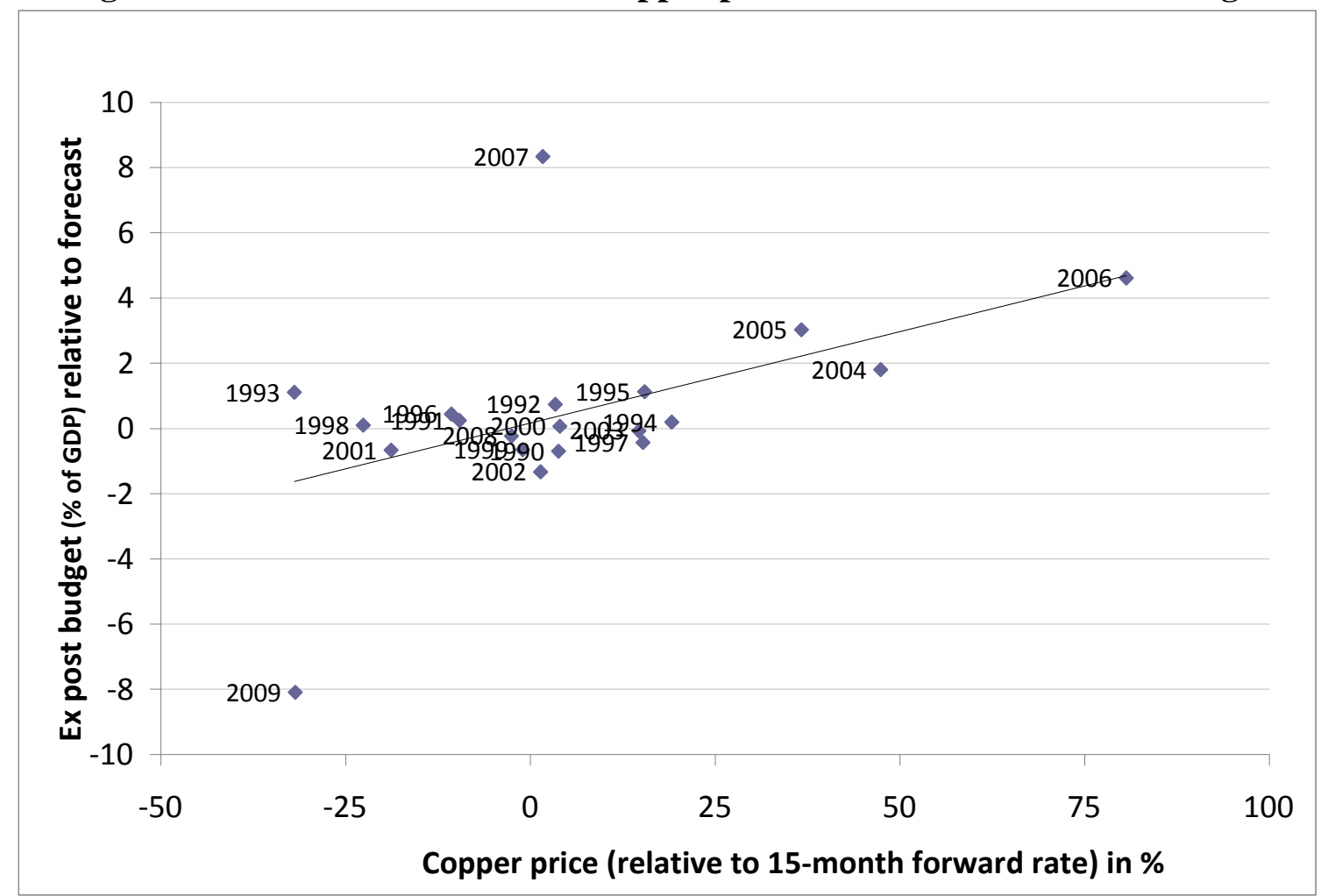

32 An Appendix in the January 2011 working paper version explains data sources. Figure 7a there uses the 10-year average of the spot price of copper, rather than the future rate used in Figure 4 here, as the benchmark for measuring short-term movements. The data then go back to 1977. Again, copper price movements are correlated with fluctuations in the budget balance. 
Table 2: Short-term determinants of Chile’s budget deficit

\begin{tabular}{lcc}
\hline \multicolumn{3}{c}{$\begin{array}{c}\text { Regression of budget balance (ex post budget relative to forecast) } \\
\text { against macroeconomic variables (ex post relative to forecast). } \\
\text { 1990-2009 (20 observations) } \\
\text { Coefficient estimates }\end{array}$} \\
VARIABLES & $\begin{array}{c}0.060^{* *} \\
(0.021)\end{array}$ & $0.056^{* *}$ \\
Copper price movement $\underline{1 /}$ & 0.239 & $(0.021)$ \\
GDP movement & $(0.187)$ & \\
& 0.023 & 0.163 \\
Constant & $(0.754)$ & $(0.683)$ \\
& 0.299 & 0.251 \\
$\mathrm{R}^{2}$ & 2.655 & 2.666 \\
RMSE & Robust standard errors in parentheses
\end{tabular}

1. The copper price movement is here measured as [log(average of end of month price, Jan.- Dec., of the next year) $-\log (\text { August } 15 \text {-month forward price) }]^{*} 100$

\section{Reasons for overshooting in mineral prices}

Conceptually, there are three different reasons why mineral prices may follow a cyclical or mean-reverting process. They are based, respectively, in mineral microeconomics, in monetary economics, and in speculative bubbles. The relative importance of the three makes no difference for the purposes of this paper.

First, it is not hard for a microeconomist to understand why the market price of minerals overshoots in the short run, or even the medium run. Because elasticities of supply and demand with respect to price are low, relatively small fluctuations in demand (due, for example, to weather) or in supply (due, for example, to disruptions) require a large change in price to re-equilibrate supply and demand. Demand elasticities are low in the short run largely because the capital stock at any point in time is designed physically to operate with a particular ratio of mineral inputs to output, with little scope for substitution. Supply elasticities are also often low in the short run because it takes time to adjust output. Inventories can cushion the short run impact of fluctuations, but they are limited in size. Scope to substitute across materials is also limited.

As time passes, elasticities become far higher, both on the demand side and the supply side. As a result prices come back down in the aftermath of a spike. In the medium term, mineral prices may be subject to a cobweb cycle, due to the lags in response: The initial market equilibrium is a high price; the high price cuts demand after some years, which in turn leads to a new low price, which raises demand with a lag, and so on.

The second possible explanation for a cycle in mineral prices is monetary overshooting. ${ }^{33}$ Since the Hotelling (1931) theory of non-renewable resources, we have known that the decision whether to leave deposits in the ground versus to extract and sell them at today's price should be governed by an arbitrage condition between the interest rate, on the one hand, and expected future rate of increase in the mineral price on the

${ }^{33}$ Frankel (1986, 2008a). 
other hand. The expected future rate of price increase, in turn, should be related to any perceptions that today's price is below its long-run equilibrium price. A similar arbitrage condition holds with respect to the decision whether to hold inventories or to sell them, but storage costs are added to the interest rate on the carrying-cost side of the ledger, while convenience yield is added to expected future appreciation on the benefits side.

The key implication is an inverse relationship between real interest rates and real commodity prices. If the real interest rate is high, it undercuts the incentive to hold minerals underground or in inventories. The result is a fall in demand or rise in supply, which drives down the spot price of the mineral. The market is in short-run equilibrium when the mineral is sufficiently undervalued (relative to its long-run equilibrium) that a general perception of future price increases is sufficient to offset the higher real interest rate, thereby restoring the arbitrage condition.

That much is Hotelling. Now we add monetary cycles. A currently high real interest rate can be the result of transitorily tight monetary policy. In the medium run, the real interest rate tends to return to its medium-run equilibrium; as a result, the real commodity price also returns to its equilibrium. According to this view, low real interest rates in the 1970s and 2000s led to high global prices for oil and minerals, and high real interest rates in the 1980s and 1990s led to low prices for oil and minerals.

The third possible explanation for mean-reversion is speculative bubbles, defined as a self-confirming or bandwagon process that carries the commodity price away from its fundamentals. Speculators know that the bubble might pop and the price return to its fundamental value. But they weigh the probability, in each given month, that the bubble will end (so that they will lose money if they stay in the market) against the probability that it will continue another month (so that they will lose money if they get out of the market). Theory does not have much to say about when or under what conditions bubbles get started, or stop. But it seems that they usually start on the back of a trend that originated in fundamentals, whether microeconomic (as in the first theory above) or monetary (as in the second).

\section{Evidence of reversion to long run equilibrium in real copper prices}

We now turn to the empirical evidence on copper prices. Is a high price in fact likely, statistically, to be followed eventually by a reversion to the long-run mean? Cuddington and Jerrett (2008) find three "super cycles" in prices of copper and four other metals, over the 150 years from 1850-2000, followed by the beginnings of a fourth super cycle. But the tendency for commodity prices to revert from historic highs back to long run equilibrium is too weak to show up statistically in a few decades of data. This is true even though the tendency to revert may be strong enough to wreck national economies, implausible as that juxtaposition may sound at first. Statistically, one needs a lot of data to reject a random walk (or to establish a permanent trend). There is not enough power in tests on time series of prices that are only a few decades long.

One can illustrate this proposition either via empirical evidence or a priori theory. Tables $3 \mathrm{a}$ and $3 \mathrm{~b}$ regress the change in the real copper price against its lagged value, respectively, with and without a trend. In a deliberate attempt to mimic many other studies, the tests in Table 3 use only 30 years of data, starting in 1980. The real 
price of copper for this period is illustrated in Appendix Figure 1. The estimated trend is positive, but not significant. ${ }^{34}$ More importantly for present purposes, the coefficient on the lagged real price of copper is negative, but not significant. (We use Dickey-Fuller critical levels, which require a test statistic of 3.6 to give significance at the $5 \%$ level, or about 3 to give significance at the $10 \%$ level.) Putting the significance question aside momentarily, the point estimate is about -0.1 when the process is estimated without a trend, suggesting that about $10 \%$ of the gap between the real price of copper and its longrun average is closed each year in the absence of new disturbances.

Why is the reversion parameter not significant? Economists often observe such failures to reject the null hypothesis of a random walk, and then jump to language implying that the variable in question actually follows a random walk. But the two propositions are different, as any introductory statistics student is taught. The difference lies in the statistical power of the test.

Imagine that the true speed of adjustment is indeed 0.1 . In other words, the autoregressive coefficient for the real copper price is 0.9. A simple calculation can illustrate why one would not expect 30 or 40 years of data to give enough statistical power to reject a unit root (random walk) even if none were there. The asymptotic standard error of an estimate of an autoregressive coefficient AR is approximately the square root of $\left(1-A R^{2}\right) / N$. So the t-ratio to test the null hypothesis that $\mathrm{AR}=1$ is:

$$
(1-A R) / \sqrt{\left[\left(1-A R^{2}\right) / N\right]} \text {. }
$$

If the true speed of adjustment is on the order of 10 per cent per year $(A R=.9)$, we can compute the number of years of data that we would expect to need in order to have enough power to reject the null hypothesis $(t>3)$ as:

$$
\begin{gathered}
(1-.9) / \sqrt{ }\left[\left(1-.9^{2}\right) / N\right]>3 . \\
N>[3 /(1-.9)]^{2}\left(1-.9^{2}\right)=[30]^{2}(.19)=171 .
\end{gathered}
$$

In other words, one should expect to require something like 171 years of data in order to be able to reject the null hypothesis of a unit root. ${ }^{35}$ If one only has 30 years of data it would be surprising if one succeeded in rejecting $A R=1$. It would be analogous to Gregor Mendel's famous experiments with peas, where the results matched the theoretical predictions of gene theory so perfectly that Ronald Fisher (1936) later argued on probabilistic grounds that he must have cheated.

\footnotetext{
${ }^{34}$ Some authors find a small upward trend in mineral prices, some a small downward trend. The answer seems to depend, more than anything else, on the date of the end of the sample. Studies written after the commodity price increases of the 1970s found an upward trend, but those written after the 1980s found a downward trend, even when both kinds of studies went back to the early $20^{\text {th }}$ century. No doubt, when studies using data through 2008 are completed some will again find a positive long run trend. References include Cuddington (1992), Cuddington, Ludema and Jayasuriya (2007), Cuddington and Urzua (1989), Grilli and Yang (1988), Pindyck (1999), Hadass and Williamson (2003), Reinhart and Wickham (1994), Kellard and Wohar (2005), Balagtas and Holt (2009) and Harvey, Kellard, Madsen and Wohar (2010).

${ }^{35}$ Because the formula for the standard error is asymptotic, one should perhaps not take this calculation too literally. But the implication that one needs something like 200 years of data to reject a random walk can be further supported in several ways: more elaborate a priori calculations, trying the test out on varying time samples of actual data or Monte Carlo studies. These points regarding random walk test power were made some years ago in the context of real exchange rates.
} 
Table 3: Test for mean-reversion in copper price: 1980-2009 (30 observations)

Table 3a: with trend

\begin{tabular}{|c|c|c|c|c|}
\hline & Test Statistic & $1 \%$ C.V. & $5 \%$ C.V. & $10 \%$ C.V \\
\hline $\mathrm{Z}(\mathrm{t})$ & -1.512 & -4.334 & -3.58 & -3.228 \\
\hline
\end{tabular}

MacKinnon approximate $\mathrm{p}$-value for $\mathrm{Z}(\mathrm{t})=0.017$

\begin{tabular}{|l|r|r|r|r|}
\hline Change in log of real copper price & Coefficient. & \multicolumn{1}{l|}{ Std. Err. } & \multicolumn{1}{l|}{$\mathrm{T}$} & \multicolumn{1}{l|}{$\mathrm{P}>|\mathrm{t}|$} \\
\hline Lagged real copper price & -0.148 & 0.098 & -1.51 & 0.142 \\
\hline Trend & 0.006 & 0.004 & 1.38 & 0.179 \\
\hline Constant & -0.808 & 0.479 & -1.69 & 0.103 \\
\hline
\end{tabular}

Table 3b: without trend

\begin{tabular}{|l|l|l|l|l|}
\hline & Test Statistic & $1 \%$ C.V. & $5 \%$ C.V. & $10 \%$ C.V \\
\hline$Z(t)$ & -1.576 & -3.716 & -2.986 & -2.624 \\
\hline
\end{tabular}

MacKinnon approximate $\mathrm{p}$-value for $\mathrm{Z}(\mathrm{t})=0.287$

\begin{tabular}{|l|r|r|l|l|}
\hline Change in log of real copper price & Coefficient. & \multicolumn{1}{|l|}{ Std. Err. } & \multicolumn{1}{l|}{$\mathrm{T}$} & $\mathrm{P}>|\mathrm{t}|$ \\
\hline Lagged log of real copper price & -0.157 & 0.099 & -1.58 & 0.126 \\
\hline Constant & -0.765 & 0.486 & -1.58 & 0.126 \\
\hline
\end{tabular}

Table 4: Test for mean-reversion in copper price: 1784-2009 (217 observations)

Table 4a: with Trend

\begin{tabular}{|l|l|l|l|l|}
\hline & Test Statistic & $1 \%$ C.V. & $5 \%$ C.V. & $10 \%$ C.V \\
\hline$Z(t)$ & -3.799 & -4.001 & -3.434 & -3.134 \\
\hline
\end{tabular}

MacKinnon approximate $\mathrm{p}$-value for $\mathrm{Z}(\mathrm{t})=0.017$

\begin{tabular}{|l|r|r|r|r|}
\hline Change in log of real copper price & \multicolumn{1}{|l|}{ Coefficient } & \multicolumn{1}{l|}{ Std. Err. } & \multicolumn{1}{l|}{$\mathrm{T}$} & \multicolumn{1}{l|}{$\mathrm{P}>|\mathrm{t}|$} \\
\hline Lagged real copper price & -0.1284 & 0.0338 & -3.80 & 0.000 \\
\hline Trend & -0.0010 & 0.0003 & -3.20 & 0.002 \\
\hline Constant & -0.4228 & 0.1117 & -3.78 & 0.000 \\
\hline
\end{tabular}

Table 4b: without trend

\begin{tabular}{|l|l|l|l|l|}
\hline & Test Statistic & $1 \%$ C.V. & $5 \%$ C.V. & $10 \%$ C.V \\
\hline$Z(t)$ & -2.000 & -3.471 & -2.882 & -2.572 \\
\hline
\end{tabular}

MacKinnon approximate $\mathrm{p}$-value for $\mathrm{Z}(\mathrm{t})=0.287$

\begin{tabular}{|l|r|r|r|r|}
\hline Change in log of real copper price & \multicolumn{1}{|l|}{ Coefficient. } & \multicolumn{1}{|l|}{ Std. Err. } & \multicolumn{1}{l|}{$\mathrm{T}$} & \multicolumn{1}{l|}{$\mathrm{P}>|\mathrm{t}|$} \\
\hline Lagged log of real copper price & -0.0357 & 0.0178 & -2.00 & 0.047 \\
\hline Constant & -0.1523 & 0.0748 & -2.04 & 0.043 \\
\hline
\end{tabular}


Fortunately, for a commodity such as copper, it is easy to get data going back two centuries and more. Tables $4 \mathrm{a}$ and $4 \mathrm{~b}$ repeat the same statistical tests with over 200 years of data, starting in $1784 .^{36}$ More importantly, the coefficient on the lagged real copper price is now statistically significant as well, showing an estimated tendency to revert to equilibrium at a speed of 0.13 per year. The autoregressive coefficient is less than one, not just at the $10 \%$ level of statistical significance, but also at the $5 \%$ level. Just as the a priori calculation suggested, mean reversion is there, but one needs two centuries of data to see it.

\section{Private forecasts of copper prices}

Do copper price forecasters internalize the long-term data which imply that a large increase in the current spot price of copper is likely to be partially reversed in the future? Or do they subscribe to the random walk hypothesis, consistent with shorter time samples? As an attempt to measure private forecasts we use the futures markets, although we have only a decade of data. As can be seen in Figure 5, when the spot price of copper rises the forward price rises less than proportionately, implying a forecast of a possible future reversal. The graph also shows the official Chilean estimate of the long run copper price produced by the expert panel. It rose even less than the forward price during the spike of 2006-08, behaving much like the 10-year moving average, as it is supposed to do. Apparently the panel, like the private markets, does indeed internalize the tendency of the price to revert toward its long run trend.

\footnotetext{
${ }^{36}$ The time series constructed from Historical Statistics of the United States obtains the price of copper from different locations in different periods: Philadelphia - 1784-1824; Sheathing-1825-1859; Copper Lake-1860-1906; New York-1907-1926; Connecticut_-1927-1977; BLS -1978-1998. The real price is the current dollar price divided by the BLS-based CPI. The 225-year history of the real price of copper is graphed in Appendix Figure 2 of the January 2011 working paper. The trend is statistically significant, but negative.
} 
Figure 5: Copper prices - spot, forward, and forecast, 2001-2010

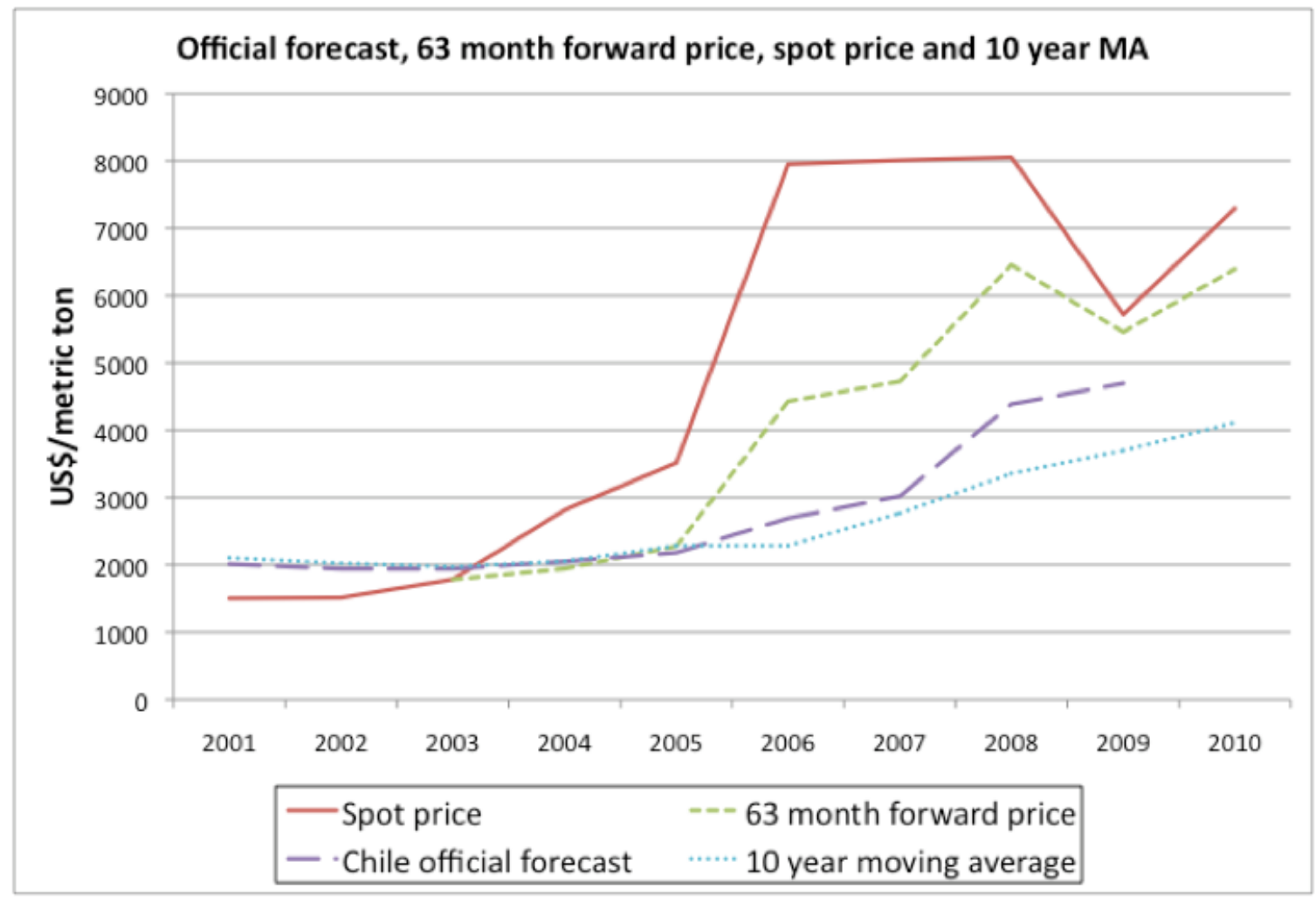

In Table 5 we test formally the hypothesis that private forecasters - to the extent their monthly expectations are reflected in the forward market - believe in meanreversion in the real price of copper. The dependent variable is the expected future rate of change in the real copper price, with expectations measured by the forward rate at a monthly frequency. At all three horizons (15 month, 27 month, and 63 month) the results strongly support the hypothesis.

Table 5: Does the private market recognize mean reversion in copper prices?

\begin{tabular}{lccc}
\hline & \multicolumn{3}{c}{ Dependent variable: $\log$ (real forward price / real spot price) } \\
\hline & $(1)$ & $(2)$ & $(3)$ \\
VARIABLES & 15-month horizon & $27-$-month horizon & 63 -month horizon \\
\hline Spot price real & $-0.0016^{* * *}$ & $-0.0029^{* * *}$ & $-0.0047^{* * *}$ \\
& $(0.0002)$ & $(0.0003)$ & $(0.0009)$ \\
Constant & $0.0232^{* * *}$ & $0.0405^{* * *}$ & -0.0119 \\
& $(0.0070)$ & $(0.0116)$ & $(0.0466)$ \\
Observations & 258 & 204 & 93 \\
$\mathrm{R}^{2}$ & 0.147 & 0.232 & 0.186 \\
RMSE & 0.0631 & 0.0980 & 0.201 \\
\hline
\end{tabular}

$* * * \mathrm{p}<0.01, * * \mathrm{p}<0.05, * \mathrm{p}<0.1$

Robust standard errors in parentheses

LHS variable is [ $\ln \left(\right.$ real forward price)- $\ln (\text { real spot price) }]^{*} 100$

The sample for the 15-month forward is January 1989-July 2010. 27-month is July 1993-July 2010. 63-month starts October 2002. RHS variables: Real spot price and a constant Real price $\equiv$ nominal price divided by US CPI.

Data source: LME via Bloomberg for copper prices. IMF IFS for US CPI. 
Even though real copper prices have a tendency to revert to a long-run trend and the forward market seems to internalize this tendency, we should not fail to appreciate how strong is the temptation to believe that big changes in the price are permanent, particularly big increases. The temptation would be especially understandable if uncertainty were genuinely higher after big increases in the price; it would be harder for naysayers to object.

The next hypothesis to be tested is that uncertainty is indeed higher at the top of the cycle. We measure uncertainty by the volatility that is implicit in options prices. We estimate the middle of the cycle as the long-run trend value of the real price, estimated over the entire sample period 1784-2009. Unfortunately, we have options data only from 2004 to 2009 , and the copper price during all of this period was above our measure of the long-run trend price. Thus we can only test the hypothesis that uncertainty becomes unusually high as the price moves toward the upper range of the price cycle. We cannot rest the symmetric hypothesis that uncertainty is also unusually high toward the lower part of the cycle. Table 6 confirms the hypothesis, at high significance levels for options prices of five of the six horizons tested. Evidently uncertainty does indeed rise as the copper price moves far above its long-run trend value. Figure 6 graphs the positive relationship between option-implied volatility and the level of the spot price. ${ }^{37}$ This finding is consistent with the hypothesis that forecasting is especially difficult in a boom.

\section{Table 6: Is Uncertainty Greater When the Copper Price is Above its Long-run Trend?}

Regression of option-implied copper price volatility on $\log$ (real spot price) - linear trend (log real spot price, using data for 230 years)

\begin{tabular}{|c|c|c|c|c|c|c|}
\hline VARIABLES & $\begin{array}{c}\text { (1) } \\
12 \text { month }\end{array}$ & $\begin{array}{c}(2) \\
15 \text { month }\end{array}$ & $\begin{array}{c}(3) \\
24 \text { month } \\
\end{array}$ & $\begin{array}{c}\text { (4) } \\
27 \text { month } \\
\end{array}$ & $\begin{array}{c}\text { (5) } \\
39 \text { month } \\
\end{array}$ & $\begin{array}{c}(6) \\
63 \text { month }\end{array}$ \\
\hline \multirow{2}{*}{$\begin{array}{l}\text { Real copper price } \\
\text { (diff. vs. LR trend) }\end{array}$} & $7.339 * *$ & $8.377 * * *$ & $9.903 * * *$ & $10.04 * * *$ & $9.506 * * *$ & -2.143 \\
\hline & $(3.190)$ & (3.017) & $(2.822)$ & $(2.775)$ & $(2.677)$ & $(1.522)$ \\
\hline Constant & $\begin{array}{c}29.19^{* * *} \\
(2.624)\end{array}$ & $\begin{array}{c}27.74 * * * \\
(2.489)\end{array}$ & $\begin{array}{c}24.88 * * * \\
(2.381)\end{array}$ & $\begin{array}{c}24.32 * * * \\
(2.353)\end{array}$ & $\begin{array}{c}23.42 * * * \\
(2.276)\end{array}$ & $\begin{array}{c}31.95^{* * *} \\
(1.228)\end{array}$ \\
\hline Observations & 60 & 60 & 60 & 60 & 59 & 47 \\
\hline $\mathrm{R}^{2}$ & 0.109 & 0.150 & 0.226 & 0.238 & 0.242 & 0.027 \\
\hline RMSE & 7.108 & 6.750 & 6.206 & 6.082 & 5.675 & 3.688 \\
\hline
\end{tabular}

37 The upper left branch shows the high volatility in the aftermath of the Lehman failure in late 2008, which works here to vitiate the relationship (and to reverse it in column 6 , which misses the early years). 


\section{Figure 6: Uncertainty is higher when the copper price is above its long run average}

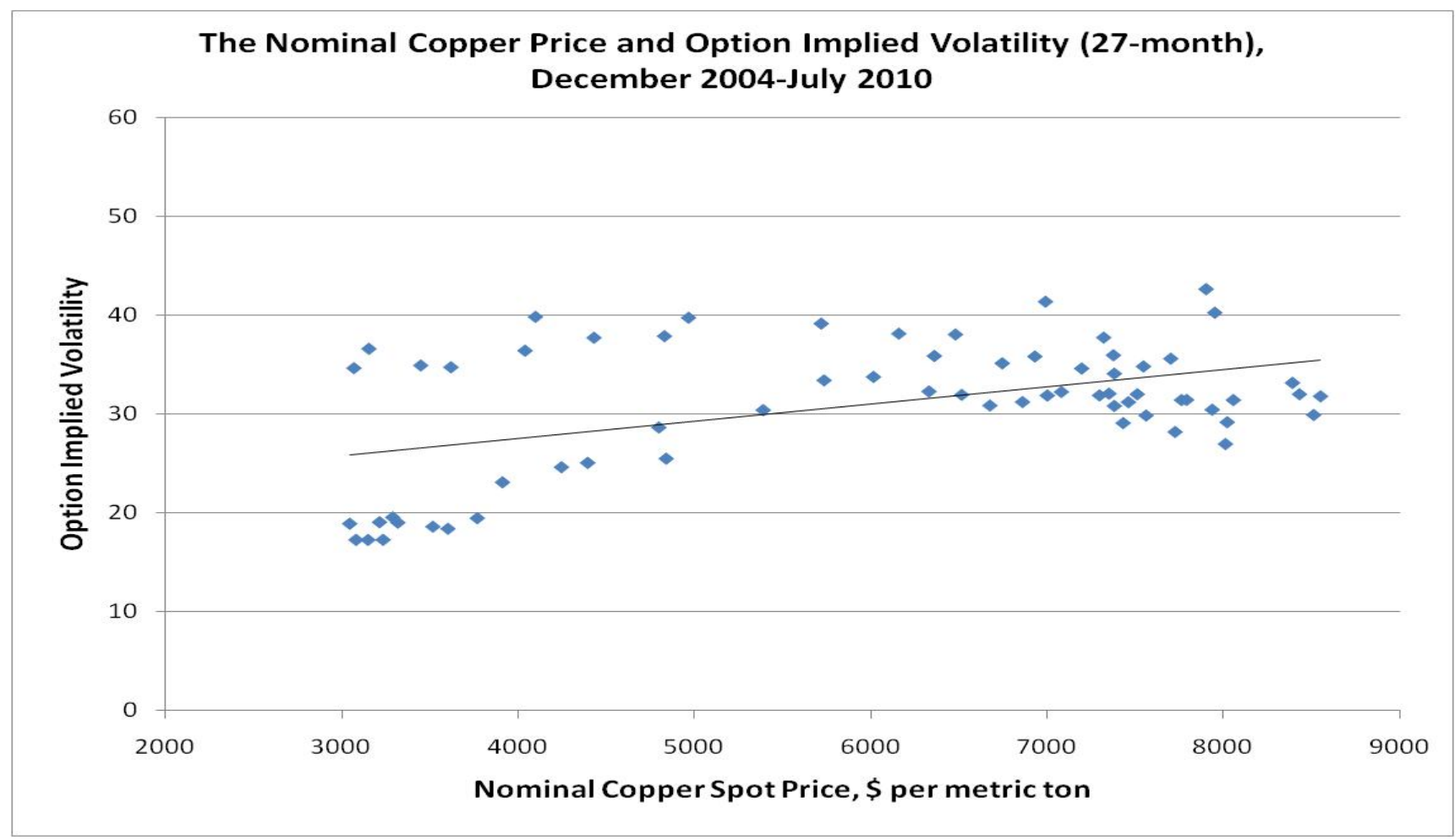

\section{Econometric tests of over-optimism in government forecasts}

Of the various ways that governments can fail to save enough, especially in boom times, the one of central interest in this paper is the possibility that official forecasts of revenue are overly optimistic. If the official forecast is optimistic, there is no reason to take painful steps such as cutting spending or raising taxes. The syndrome is not confined to commodity-producers. A prominent example is the overly optimistic U.S. budget forecasts made by the White House in 2001 and subsequent years. Its unrealistic forecasts were a major reason for the striking failure of the United States to take advantage of the opportunity of the 2002-07 expansion to save. ${ }^{38}$

But the pattern, and the hope for an institutional solution, come into sharper focus in the case of commodity producers.

\footnotetext{
${ }^{38}$ The White House claim that budget surpluses over the subsequent ten years would approach $\$ 5$ trillion (in round numbers) was a major factor in the political ability of the new administration to persuade the Congress to approve long-term tax cuts and spending increases. The result was that the ten-year fiscal outlook soon swung to roughly a cumulative $\$ 5$ trillion deficit. (For details and further references: Frankel, 2003, 2008b.)
} 


\section{Are official budget forecasts overly optimistic on average?}

There is evidence that government budget forecasts are overly optimistic on average, often because official estimates of economic growth are overly optimistic.

Studies of growth forecasts by US government agencies in the 1960s and 1970s used to find them generally unbiased and as accurate as private sector forecasts. But subsequent analyses found biases. McNees (1995) updated the time sample to 1994 and found an optimistic bias in some official forecasts of long-term growth. Auerbach (1994) found overly optimistic forecasts in the decade preceding 1993. Auerbach (1999) again found a tendency for the Office of Management and Budget (OMB) in its semiannual forecast to overestimate revenues during the period 1986-93, but found a tendency to underestimate revenues during the period 1993-99 (during the Clinton Administration). McNab, Rider, and Wall (2007) find that OMB's one-year ahead forecasts of US tax receipts were biased over the period 1963-2003. They suggest that the bias may be strategic on the part of various administrations seeking to achieve particular goals, such as overstating budget balance when the administration is seeking to increase spending or cut taxes. Frendreis and Tatalovich (2000) find that US administrations (OMB) are less accurate in estimating growth, inflation and unemployment than are the Congressional Budget Office and the Federal Reserve Board. They find partisan bias, which they interpret as Republican administrations' overforecasting inflation and Democratic administrations' over-forecasting unemployment.

Forni and Momigliano (2004) find optimism bias among OECD countries more generally. Ashiya (2005) finds that official Japanese growth forecasts at a 16-month horizon are biased upwards by 0.7 percentage points, and significantly less accurate than private sector forecasts. Canada evidently underestimated its budget deficits in the late 1980s and early 1990s, but subsequently (1994-2004) overestimated them, perhaps to reduce the risk of missing its target of a balanced budget under its strengthened institutional framework (O’Neill, 2005; Mühleisen, et al, 2005).

Jonung and Larch (2006) find a clear tendency for EU governments to overestimate the economic growth rate when making budget plans. A three-author team finds a statistically significant optimism bias for some euro members: France, Italy and Portugal over the period 1991-2002 (Strauch, et al., 2004), and Germany, Italy, Greece, Luxembourg, and Portugal when the data set is updated to 2004 (Von Hagen, et al, 2009). The UK, Finland and Sweden, on the other hand, tend to overestimate their deficits. Brück and Stephan (2006) explicitly conclude that Eurozone governments have manipulated deficit forecasts before elections since the introduction of the SGP. Most of these authors argue that the systematic over-optimism in ex ante forecasts translates directly into larger ex post deficits, and particularly to deficits larger than targeted under the SGP.

Similarly, Beetsma et al (2009) find that ex post budget balances among SGP countries systematically fall short of official ex ante plans. Marinheiro (2010) adds another complete business cycle to the data under the SGP, and again finds that the forecasts of European fiscal authorities are overly optimistic on average. This evidence is not consistently strong across the set of $15 \mathrm{EU}$ countries, but the bias is again high for 
France, Italy and Portugal at all forecast horizons. ${ }^{39}$

There is far less research into the forecasting records of fiscal authorities in lowincome or medium-income countries than in advanced countries. ${ }^{40}$ One reason is limited availability of data. But some major emerging market countries became more transparent about their budgets after the crises of the 1990s. One is Mexico, which now makes available data on the ex ante planned budget balance that can be compared with the ex post realized budget balance. On the one hand, if the numbers are interpreted as a forecasting exercise, then the accuracy during the period 1995-2009 is impressively high. On the other hand, there is evidence of a small bias in the direction of over-optimism: the budget deficit as a share of GDP is under-forecast by an average of 1/10th of a per cent of GDP. The mean is greater than zero, and statistically significant, but only at the $10 \%$ level. $^{41}$

Appendix Table 1 reports the mean errors made by government forecasts of the budget balance for 33 countries. ${ }^{42}$ A majority of the countries are European (26, of whom 17 are euro members if one counts Estonia, which was approved for membership in 2010). The heavy representation of these countries in the sample arises because, while most countries do not report official budget forecast data, these countries do - as a side-effect of the Stability and Growth Pact itself. But the European data will allow us below to test for the effect on forecast bias of the political pressure from a budget rule such as the SGP. Of the additional seven countries, one is the United States, three are advanced commodity-exporting countries (Australia, Canada, and New Zealand), and three are middle-sized emerging market countries that do export commodities (Chile, Mexico and South Africa). The last category is perhaps the most important for this study; but national sources must be consulted one by one, and for most developing countries the answer is that such data are not available.

The fourth column reports the official ex ante forecast minus actual ex post outcome one year ahead: mean forecast error, minimum and maximum. Some countries report forecasts two or three years ahead; these forecast errors are shown in the fifth and sixth columns, respectively. The general pattern, as suspected, is overoptimism. In most cases, the positive bias emerges more strongly at the 3-year horizon than the 2-year horizon and more at the 2-year horizon than the 1-year horizon. The average across all countries is an upward bias of $0.2 \%$ of GDP at the one-year horizon, a $0.8 \%$ of GDP bias two years ahead, and a hefty $1.5 \%$ bias three years ahead. It is no surprise that the absolute magnitude of forecast errors increases with the length of the horizon; this would be true even if forecasts were optimal. But the upward trend in the bias suggests that, the longer the horizon and the greater the genuine uncertainty, the more the scope for wishful thinking.

Interestingly, the bias is not greater for commodity producers or developing countries than it is for others, though the sample is far too small to allow a reliable test of the

\footnotetext{
${ }^{39} \mathrm{He}$ proposes delegating the macroeconomic forecasting to supranational authorities, such as the EU Commission or the IMF.

40 Chang, Franses and McAleer (2009) analyze official forecast errors for Taiwan, a newly industrialized economy, but without clear findings.

41 Table 5 and Figure 6 in the January 2011 working paper report the results.

42 An Appendix in the January 2011 working paper gives data sources for the 33 countries.
} 
difference. The US and UK forecasts have substantial positive biases around 3\% of GDP at the three-year horizon (approximately equal to their actual deficit on average; in other words, on average they repeatedly forecast a disappearance of their deficits that never came). The forecast biases in the euro countries have already been noted from the literature. But official budget forecasts in South Africa were overly pessimistic on average, as were those for Canada and New Zealand. Chile had no optimism bias - but the hypothesis of this study is that this was the result of its institutions - and Mexico has already been discussed. Neither offers forecasts beyond the one-year horizon.

\section{Are official growth forecasts overly optimistic on average?}

One likely reason for upward bias in official budget forecasts, in advanced and developing countries alike, is upward bias in economic assumptions such as economic growth and commodity pries. This is the hypothesis of central interest in this paper. But we should note that there are other possible reasons as well why official budget forecasts could be overly optimistic on average. The official forecast may represent the desired target in the plan of the executive, but there could be slippage by the time the final expenditures are made, due to the usual political pressures. ${ }^{43}$ Those who write the initial budget plan may even be fully aware of this tendency toward slippage and may place a lower priority on statistically unbiased forecasts than on setting an ambitious goal so as to achieve as strong a final outcome as possible.

Appendix Table 2 reports the mean errors made by government forecasts of the rate of growth of GDP, for 33 countries. Again the overall pattern is an upward bias on average, which rises with the length of the horizon: $0.4 \%$ when looking one year ahead, $1.1 \%$ at the two-year horizon, and $1.8 \%$ at three years. Again, the bias appears in the US and many other advanced countries, and not necessarily among the commodity producers in this sample. ${ }^{44}$ Chile on average under-forecast its growth rate, by 0.8 per cent at the one-year horizon. South Africa was just slightly too optimistic on average ( 0.2 per cent at the one-year horizon), and Mexico more so (1.7 per cent).

We next turn to cyclical patterns in the forecast errors. Fewer authors have looked for cyclical patterns in the systematic forecast errors made by national authorities than unconditional average errors.

\section{The influence of macroeconomic fluctuations on budget balances}

In the case of Chile, we already confirmed in Table 2 that the price of copper is key to ex post determination of the budget. Before we attempt to detect systematic ex ante determinants of errors made in officials forecast of budget deficits in our full sample of 33 countries, it would be useful to confirm that a few macroeconomic variables such as

\footnotetext{
${ }^{43}$ Cárdenas, Mejía, and Olivera (2009) show how this process works for Colombia. There may also be slippage that is not captured in the final budget numbers, because it takes place in "off budget" agencies or categories.

${ }^{44}$ The commodity exporters in this data set almost certainly represent some sample selection bias, in that only governments that are transparent enough to publish their budget forecasts are included, for obvious reasons. Thus we do not emphasize tests of whether official forecasts behave differently for commodity exporters than for others. Such tests appear to show that the special commodity exporters in our sample are actually less optimistic than others. [Appendix Table 3 in the January 2011 working paper.]
} 
the real growth rate are in fact key to the ex post determination of the actual budget balance. Then we will know to look to over-optimism in forecasts of these macroeconomic variables as a possible source of any observed over-optimism in budget forecasts.

In Table 7a we regress the ex post budget outcome (expressed relative to the ex ante attempt to predict it) against the ex post real growth rate (again expressed relative to the forecast), for our full set of countries. At all three horizons, the growth rate is highly significant at determining the budget balance. For every 1 per cent of growth, relative to what was forecast a year previously, the budget improves by about half that amount, relative to what was forecast a year previously. The same is true at the two-year and three-year horizons. Thus we are likely to find over-optimism in forecasting the budget where we find over-optimism in predicting real growth.

In some countries, inflation pushes taxpayers into higher tax brackets. ${ }^{45}$ Accordingly, in Table $7 \mathrm{~b}$ we add the inflation rate as another possible determinant of the budget balance. (Both are again expressed relative to the official ex ante forecasts.) The finding is that inflation does indeed translate into a strong budget surplus, to a statistically significant degree at the two- and three-year horizon. ${ }^{46}$

Table 7a: GDP as a determinant of budget balance as a \% of GDP

\begin{tabular}{lccc}
\hline & $(1)$ & $(2)$ & $(3)$ \\
VARIABLES & One year ahead & Two years ahead & Three years ahead \\
\hline GDP forecast error & $0.479 * * *$ & $0.525^{* * *}$ & $0.489^{* * *}$ \\
& $(0.060)$ & $(0.068)$ & $(0.077)$ \\
Constant & 0.155 & 0.198 & $0.556^{*}$ \\
& $(0.174)$ & $(0.249)$ & $(0.314)$ \\
Observations & 367 & 277 & 175 \\
Countries & 33 & 31 & 28 \\
$\mathrm{R}^{2}$ & 0.280 & 0.369 & 0.322 \\
RMSE & 1.695 & 2.053 & 2.327 \\
\hline
\end{tabular}

$* * * \mathrm{p}<0.01, * * \mathrm{p}<0.05, * \mathrm{p}<0.1$

Robust standard errors in parentheses.

Estimated with fixed effects (FE) by country.

\footnotetext{
${ }^{45}$ At high levels of inflation, the Tanzi effect can go the other direction: Due to lags in tax collection, inflation erodes the real value of tax receipts and can worsen the budget deficit.

${ }^{46}$ These tables allow fixed effects by country [which facilitates comparison across the three columns even though the sample of countries diminishes]. Results without fixed effects are reported in the January 2011 working paper. There the effect of inflation appeared a bit stronger statistically.
} 
Table 7b: GDP and inflation as determinants of budget balance as a \% of GDP

\begin{tabular}{lccc}
\hline & $(1)$ & $(2)$ & $(3)$ \\
VARIABLES & One year ahead & Two years ahead & Three years ahead \\
\hline GDP forecast error & $0.498^{* * *}$ & $0.466^{* * *}$ & $0.460^{* * *}$ \\
& $(0.055)$ & $(0.064$ & $(0.075)$ \\
Inflation forecast error & 0.158 & $0.196^{*}$ & $0.254^{* * *}$ \\
& $(0.109)$ & $(0.116)$ & $(0.093)$ \\
Constant & 0.331 & $0.593^{*}$ & $0.913^{* *}$ \\
& $(0.212)$ & $(0.306)$ & $(0.356)$ \\
Observations & 214 & 185 & 159 \\
Countries & 28 & 27 & 27 \\
$\mathrm{R}^{2}$ & 0.351 & 0.402 & 0.351 \\
RMSE & 1.634 & 2.127 & 2.313 \\
\hline
\end{tabular}

$* * * \mathrm{p}<0.01, * * \mathrm{p}<0.05, * \mathrm{p}<0.1$

Robust standard errors in parentheses.

FE by country.

All variables are lagged so that they line up with the year in which the forecast was made, not the year being forecast.

\section{Are budget forecasts more prone to over-optimism in booms?}

We now return to examination of bias in government forecasts. In Table 8 we go beyond testing for unconditional over-optimism in official budget forecasts, to see if the bias is greater in a boom, here measured as the deviation of output from a quadratic trend. The cyclical term is indeed positive and highly significant: over-optimism tends to be greater in booms. Its estimated magnitude rises as we move from the one year from horizon to the two year horizon, and again as we move to the three year horizon. This makes sense: there is more scope for wishful thinking at longer horizons because the uncertainty is genuinely higher. But there is still also evidence of a bias toward optimism even when GDP is at its trend value.

Table 8: Budget balance forecast error as \% of GDP, Full dataset

\begin{tabular}{lccc}
\hline VARIABLES & $(1)$ & $(2)$ & $(3)$ \\
\hline GDPdevq & One year ahead & Two years ahead & Three years ahead \\
& $0.093^{* * *}$ & $0.258^{* * *}$ & $0.289 * * *$ \\
Constant & $(0.019)$ & $(0.040)$ & $(0.063)$ \\
& 0.201 & $0.649 * * *$ & $1.364 * * *$ \\
Observations & $(0.197)$ & $(0.231)$ & $(0.348)$ \\
$\mathrm{R}^{2}$ & 398 & 300 & 179 \\
RMSE & 0.033 & 0.113 & 0.092 \\
\hline
\end{tabular}

Variable is lagged so that it lines up with the year in which the forecast was made and not the year being forecast. $* * * \mathrm{p}<0.01, * * \mathrm{p}<0.05, * \mathrm{p}<0.1$

Robust standard errors in parentheses, clustered by country. 
The findings are visible in Figures $7 \mathrm{a}$ and $7 \mathrm{~b}$. First, budget forecasts in most countries are biased upwards. (Most points appear above the zero level of budget prediction error). Second, Chile is an exception. (The Xs in Figure 7a mostly lie below the zero level.) Third the bias is greater at longer horizons. (Compare the two Figures.) And fourth, the bias is greater in booms. (A regression line slopes upward.) ${ }^{47}$

Figure 7a: Chile's budget forecasts are not prone to the optimism bias of others

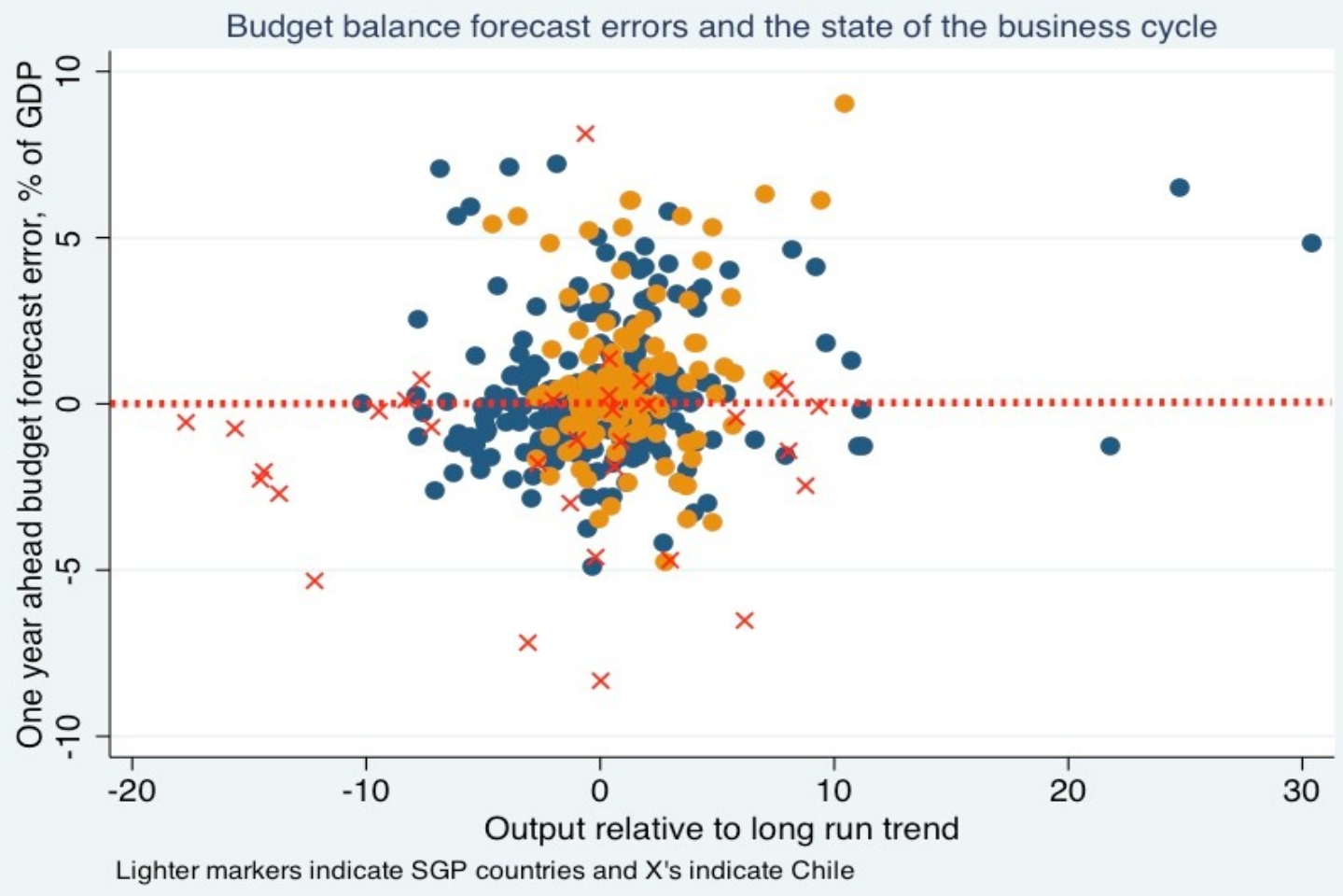

\footnotetext{
${ }^{47}$ The country with longest sample period at the 1-year horizon is Chile (1977-2009): figure 7a. At the 2year horizon, the United States has the longest sample period (1987-2009): figure 7b in the January 2011 working paper. At the three-year horizon numerous European countries have a sample period of 20012009: figure $7 \mathrm{~b}$ here [figure $7 \mathrm{c}$ in the original working paper]. For the individual country sample periods, see Appendix Table 1 to the original.
} 
Figure 7b: The bias is greater at the 3-year horizon and is greater in booms

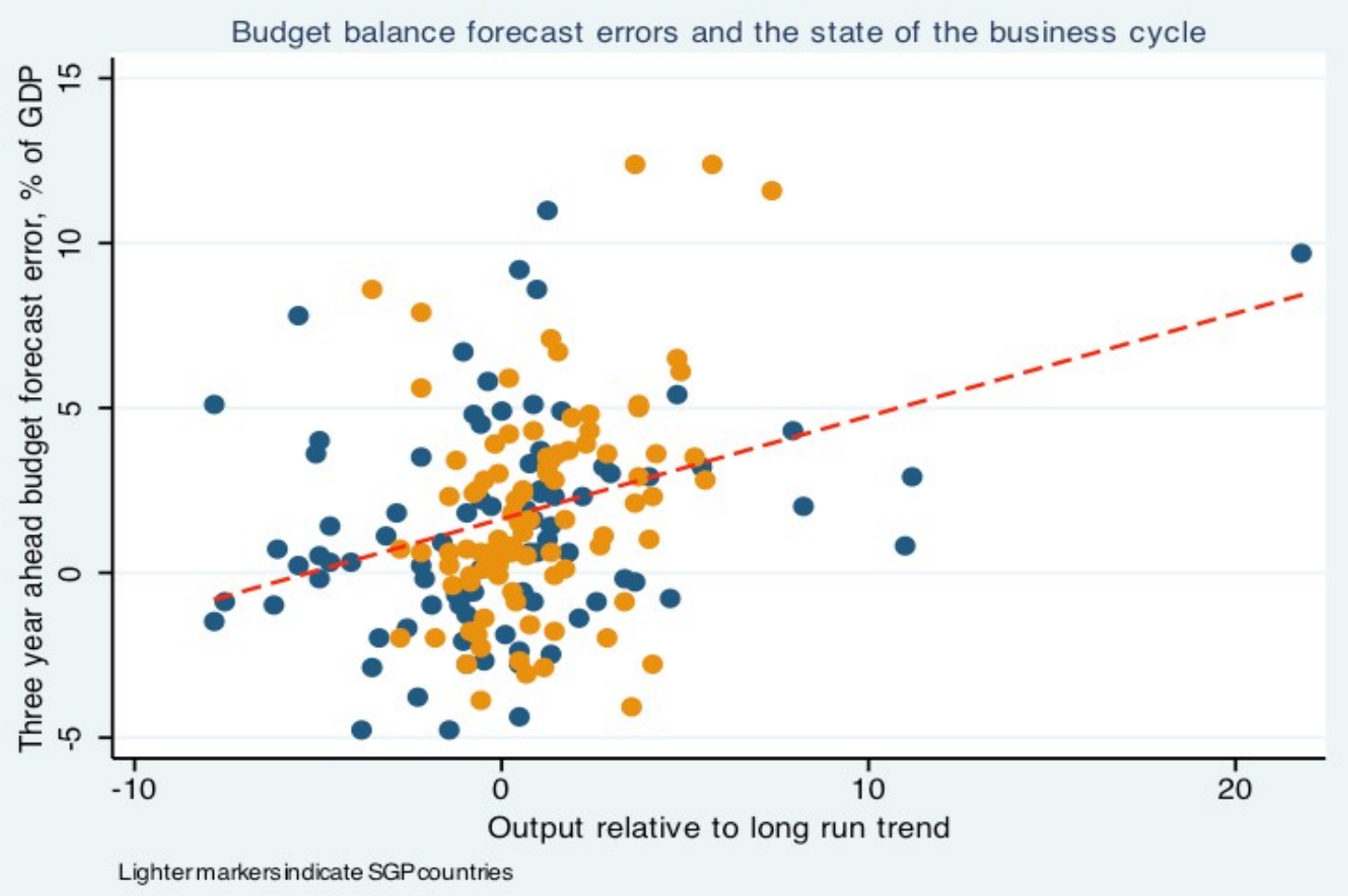

\section{Are official budget forecasts more prone to over-optimism when the country is subject to a budget rule?}

It is highly suggestive that Italy and other Mediterranean countries, the EU countries that had to work the hardest to meet the Maastricht fiscal criteria, are also the ones found by several studies to have had the greatest bias in their forecasts. Recall that in the estimates of Lonung and Larch (2006), the UK does not show significant overoptimism. Since the UK has not sought entrance into the euro, their finding is consistent with the possibility that the bias is euro-related. Thus the literature is consistent with the hypothesis that formal adoption of a budget deficit ceiling may, by itself, induce a tendency toward over-optimism in official forecasts, but that over-optimism can be counteracted by the right sort of fiscal regime or institution.

We report regression of our own tests of the "planning to cheat" hypothesis, on a bigger data set than the earlier studies. The examples of rule-bound countries are the euro members, as in the literature. ${ }^{48}$ But rather than comparing them only to other European countries, we also include others, including a number of commodity producers.

Our data confirm the finding that the European countries in general, and the SGP countries in particular, are prone to overly optimistic budget forecasts in our data set. The bias is stronger for the euro countries, the more so the longer the forecast horizon. We have tested for a cyclical pattern in the over-optimism, by including a term for the interaction of the dummy for countries subject to the Stability and Growth Pact and their

\footnotetext{
${ }^{48}$ New Zealand and Switzerland are other examples of countries with rules that put ceilings on the deficit and debt - Marcel, Tokman, Valdés, and Benavides (2001).
} 
GDP expressed as a deviation from its long run trend. ${ }^{49}$ The coefficient is statistically significant. The positive sign confirms the extrapolative nature of the forecasters' optimism: when the business cycle is at its peak, the government forecasters are more prone to give free reign to wishful thinking. The results are very similar regardless whether the data set includes just Western European countries, all European countries, or our complete set of countries.

\section{Is over-optimism in growth forecasts worse in booms?}

We saw above that for most countries, the evolution of the actual budget deficit at a one-year horizon is heavily influenced by the evolution of the economy, particularly GDP. In this section we test if the cyclical component to errors in budget forecasting derives to some extent from an analogous cyclical component to errors in economic forecasting. Table 10 tests if growth forecasts tend to be more overoptimistic when the economy is at a cyclical peak, here measured as the deviation of GDP from a quadratic trend. The answer is a resounding yes, especially as the horizon of the forecast lengthens, just as we found with forecasts of the budget deficit.

\section{Table 10: GDP Growth Rate Forecast Error}

\begin{tabular}{lccc}
\hline & $(1)$ & $(2)$ & $(3)$ \\
VARIABLES & One year ahead & Two years ahead & Three years ahead \\
\hline GDPdevq & $0.204^{* * *}$ & $0.497^{* * *}$ & $0.668^{* * *}$ \\
& $(0.033)$ & $(0.078)$ & $(0.159)$ \\
Constant & $0.265^{* * *}$ & $0.799^{* * *}$ & $1.600^{* * *}$ \\
& $(0.091)$ & $(0.130)$ & $(0.247)$ \\
Observations & 368 & 282 & 175 \\
Countries & 33 & 31 & 28 \\
$\mathrm{R}^{2}$ & 0.138 & 0.298 & 0.303 \\
RMSE & 2.234 & 2.945 & 3.306 \\
\hline
\end{tabular}

$* * * \mathrm{p}<0.01, * * \mathrm{p}<0.05,{ }^{*} \mathrm{p}<0.1 \quad$ Robust standard errors in parentheses, clustered by country. Country Fixed Effects. GDP devq $\equiv$ GDP as deviation from quadratic trend.

Variable is lagged so that it lines up with the year the forecast was made in and not the year being forecast.

The next step is to see if the pattern is worse among rule-bound countries. In every case, the term that interacts the SGP dummy with GDP has a significantly positive effect on the error made in forecasting output, very much like the positive effect in forecasting the budget. ${ }^{50}$ In other words, when the economy is at a cyclical high in rulebound countries, forecasters tend to extrapolate, as if the boom would last forever.

\section{Are official forecasts overly optimistic at cyclical lows as well as highs?}

We have noted some evidence consistent with the idea that over-optimism thrives when genuine uncertainty is higher, namely the pattern whereby it increases with the horizon of the forecast. Uncertainty is probably greater at cyclical highs and lows, because it is difficult to tell whether the recent movement is temporary or permanent.

\footnotetext{
49 Tables 9a, 9b, and 9c of the January 2011 working paper. The coefficient's estimated magnitude and statistical significance rise with the horizon of the forecast.

${ }^{50}$ Tables $11 \mathrm{a}, 11 \mathrm{~b}$, and $11 \mathrm{c}$ in the January 2011 working paper.
} 
These considerations suggest a further hypothesis worthy of testing: that forecasts are overly optimistic not just at the top of the business cycle, but at the bottom as well. The simplest way to test this hypothesis is to transform our cyclical independent variable, which has been expressed as the deviation of GDP from trend, to the absolute value of that deviation. The hypothesis is strongly borne out, both offers strong support for the hypothesis, as a characterization of both bias in official forecasts of the budget balance and bias in official forecasts of economic growth. ${ }^{51}$ Evidently official forecasters are overly optimistic both in booms and busts, more so than when GDP is at its long-run trend. They over-estimate the permanence of the booms and the transitoriness of the busts. $^{52}$

\section{Summary of statistical findings}

We re-state here our 15 econometric results.

1. The real price of copper tends to revert toward its long run trend, but the tendency can only be statistically detected when the time series history runs for as long as a century or two. For those whose memories only encompass a few decades of data, statistical power is lacking. Thus a departure of the price of copper from its long run trend, such as the 2003-08 boom, can easily but erroneously appear to be permanent.

2. Further illustrating the difficulty of forecasting in the midst of a boom, the optionimplied volatility is higher when the real price of copper lies far above its long-run trend value.

3. Official forecasts of future budgets in a sample of 33 countries are on average overly optimistic.

4. The bias toward over-optimism in budget forecasts is stronger the longer the horizon (from 1 to 2 to 3 years). At the 3-year horizon, the average is an upward bias of $1.5 \%$ of GDP.

5. Official forecasts of the budget in the US and Europe are overly optimistic on average.

6. Chile's official forecasts are not overly optimistic on average.

7. The same patterns show up in official forecasts of rates of growth in real GDP among 33 countries: overly optimistic on average, more so at longer horizons ( $1.8 \%$ at the 3 -year horizon), but not overly optimistic for Chile.

8. Forecasting GDP is a major component of forecasting the budget: prediction errors in the former are highly significant determinants of prediction errors in the latter.

9. In Chile, errors in predicting the price of copper are highly significant determinants of errors in predicting the budget; indeed GDP is not a statistically significant determinant of the budget when controlling for the copper price.

10. The bias in official budget forecasts among 33 countries is statistically correlated with the business cycle: over-optimism is higher in booms.

11. The tendency for over-optimism in government budget forecasts and growth forecasts to rise in booms is particularly strong in European countries that are

\footnotetext{
${ }^{51}$ Reported in Tables 12a and Table 13a, respectively, of the working paper.

${ }^{52}$ The patterns are worse for Europeans than for others. Tables $12 \mathrm{~b}$ and $13 \mathrm{~b}$ of the January 2011 working paper.
} 
formally subject to the Stability and Growth Pact, especially at the two- and threeyear horizons.

12. There is also statistical evidence for the proposition that budget forecast bias is related to the absolute value of the deviation of GDP from its long run trend, in other words that over-optimism occurs at the bottom of the business cycle as well as the top. But the R-squared is not quite as high as in the earlier formulation.

13. The same pattern holds for bias in forecasts of GDP: there is some support for the hypothesis that over-optimism increases at both ends of the cycle, but the fit is not quite as good as for the hypothesis that it increases at the top of the cycle.

14. There is no consistent relationship between budget forecast errors and the copper price in Chile, suggesting that the country has avoided the problem common in other countries.

Taken together, these results tell a coherent story. Among many countries there is a tendency toward wishful thinking in official forecasts of growth and the budget.

Governments unrealistically extrapolate booms three years into the future. The bias is worse among the European countries that are supposedly subject to the budget rules of the Stability and Growth Pact, presumably because those in the government who make the forecasts feel pressured to be able to announce that they are on track to meet the budget targets even if they are not. Chile has a budget rule, but is not subject to the same bias toward over-optimism in forecasts of the budget, growth, or the all-important copper price. This evidence is consistent with the idea that the key innovation that has allowed Chile in general to achieve countercyclical fiscal policy and in particular to run surpluses in booms is not just a structural budget rule in itself, but rather the regime that entrusts to two panels of independent experts the responsibility for estimating the extent to which contemporaneous copper prices and GDP have departed from their long-run averages.

\section{Countercyclical fiscal institutions generalized for other countries}

Any country could apply variants of the Chilean fiscal device. This is especially true for producers of oil and minerals. ${ }^{53}$ Countries that do not rely on commodities could also consider versions tailored to their own circumstances. Much like mineral producers, countries prone to natural disasters can prepare by putting aside savings in good years. In both cases, independent expert panels could estimate the relevant parameters. Even large diversified industrialized countries could set up independent institutions charged by law with estimating the output gap and such other budget-relevant macroeconomic variables as the inflation rate and the fractions of GDP going to wage versus non-wage income.

Given that many countries, especially in the developing world, are prone to weak institutions, a useful reinforcement of the Chilean idea would be to formalize the details

\footnotetext{
${ }^{53}$ Ecuador at one point had institutions designed to increase national saving during an oil boom, and Colombia for both coffee and oil. But such countries often miss their targets or change their rules. Perry (2003, 18-19) and Villafuerte et al (2010).
} 
of the procedure into law and give the panels legal independence. There could be laws protecting them from being fired, as there are for governors of independent central banks. There need not be any departure from the principle of separation of decision-making powers: the rules as interpreted by the panels help determine the total amount of spending and budget deficits, while the elected political leaders determine how that spending is allocated and how tax revenue is raised.

Two technical questions remain: how much of the structural budget calculations are to be delegated to the independent panels of experts, and whether the budget rules are interpreted as ex ante or ex post.

The procedures that compute the structural balance in Chile involve a number of calculations that are in fact made inside the Ministry of Finance, rather than by the panels of experts. They apparently include estimation of trend GDP from an aggregate production function (the macro panel provides the estimates of trend levels of inputs), estimation of the long-term price of molybdenum ${ }^{54}$, estimation of mining and non-mining tax revenues, and so on. ${ }^{55}$ One could imagine moving the locus of these calculations, from the Ministry to the independent panels. This might require establishing a standing bureaucracy, in the manner of the U.S. Congressional Budget Office. CBO has managed to maintain its independence and integrity, despite the politicization of most of the rest of Washington. $^{56}$ If the new independent agency were given more comprehensive control over fiscal policy, it would then draw closer to symmetry with the delegation of monetary policy to independent central banks. ${ }^{57}$ At the opposite end of the spectrum, the panels might be charged with nothing more than computing the ten-year moving-average trend of the price of copper and real GDP.

The second, related, question is whether the targeting is to be ex ante or ex post. An ex post rule for the budget deficits would have to be phrased as a target range, or as an upper bound, because unanticipated economic developments make it impossible for anyone to hit a budget target precisely. The alternative is for the rule to be interpreted as ex ante: tax rates, spending parameters and so forth are set so as to produce the desired target if all goes precisely as expected, while recognizing that there will be unanticipated deviations during the course of the year.

The analogous issue is familiar in the context of monetary policy. If the target variable is the money supply or inflation rate, the authorities cannot be expected to hit it

\footnotetext{
${ }^{54}$ A refinement added in 2005 is that the government can run a larger deficit to the extent that the price of molybdenum is below its medium-term average, not just the price of copper.

${ }^{55}$ Marcel, Tokman, Valdés, and Benavides (2001, pp.6-17); Rodriguez (2007, pp.10-21).

${ }^{56}$ Chile's congress established a version of CBO, with a staff of three analysts, in 2003 (Santiso, 2005, p.29). The legislative branch in Chile does not have power to determine fiscal policy as it does in the United States.

57 Wyplosz (2005) and Jonung and Larch (2006) have proposed setting up an independent Fiscal Policy Committee that would reproduce what independent Monetary Policy Committees do. [Others noting the analogy with monetary policy include Alesina and Perotti (1996).] But the analogy has its limits. Few reformers suggest that the details of tax and spending policy could or should be delegated to an agency that is not directly accountable in a democratic way, even though the details of interest rate setting and asset purchases are delegated to independent central banks.
} 
exactly, as opposed to the situation when the target is the price of gold or the exchange rate. The usual approach is that the monetary authorities announce a target range for M1 or the inflation rate. Conceptually, a sincere central bank will set the range so it they can achieve an outcome within the specified range, say $95 \%$ of the time. The public can then monitor the ability of the central bank to deliver on its commitment. An alternative proposal is that the monetary authorities set the parameters so as to hit a desired ex ante inflation target. If the one true model of how the economy operates were known to the central bank, who in turn announced it to the public, the two procedures would be equivalent. In reality however, the model is highly uncertain, everyone knows that it is uncertain, and different elements among the staff and different members of the monetary policy committee vary as to their preferred models. Thus it is less practical to announce an ex ante target. [The members of the monetary policy committee would have to negotiate with each other an ever-changing common model and set of forecasts, a cumbersome way to go about negotiating a decision on monetary policy.]

In the case of the fiscal expert panels, however, setting an ex ante target may be more feasible. More precisely, the panel could be charged with evaluating whether the government's budget proposal would hit the desired structural budget target, not only if output were at potential and the copper price were at its long run equilibrium, which they already have to do under the Chilean system, but also, more comprehensively, if growth and other economic variables were at the levels expected over the coming year.

Another important modification to consider is to re-cast the rule for fiscal policy as more aggressively countercyclical. The Bachelet government apparently took steps to make the budget even more countercyclical than required by the rule - saving more in 2007-08 and spending more in 2009-10. Perhaps there is a way to formalize this degree of countercyclicality into the rule. A further possibility would be an "escape clause" for earthquakes as severe as the one that hit central Chile in February 2010. The design of rules is always subject to a tradeoff between the advantages of simplicity and the disadvantages.

\section{Concluding thoughts}

Although Chile's fiscal institutions have been studied inside Chile, they have not yet received the attention from the wider world that they merit. Some countries may want to consider emulating them.

Chile's fiscal institutions are a relatively pure example of several much broader trends. Trend number one has been the increased emphasis that institutions have received in development economics and other branches of economics over the past decade or two. It is recognized that it is not enough to recommend good fiscal policy to a country - or for the IMF to make loans to a country conditional on good fiscal policy - if the deeper political support and institutions are not there to sustain the policy. Often, however, economists neglect to give specific illustrations of what they mean by "good institutions." Exhortations as to the importance of rule of law are not enough.

In general, one would expect that institutions designed for fiscal commitment can produce more transparent and disciplined budgets. Alesina, Hausmann, Hommes, and 
Stein (1999), Stein, Talvi and Grisanti (1999) and Marcel et al (2001) find that Latin American countries attained better fiscal discipline in the 1980s and early 1990s if their institutions were more hierarchical and transparent, judged by the existence of constraints and voting rules. But, as we have seen, rigidity of the constraints on paper does not always translate into credibility of follow-through in practice. ${ }^{58}$

Trend number two is the increased importance over the last decade of primary commodities: fossil fuels, minerals, and agricultural products. After two decades of lower real prices, almost all minerals and other commodities experienced a major boom in the years 2003-2008. With the commodity boom, issues of how to manage volatility, Dutch Disease, and the Natural Resource Curse returned. The need, then, is for institutions to help manage the commodity cycle, in line with trend number one. It is good news that we now have examples of regimes that are designed to guard against the human nature to overspend when commodity prices go up.

Trend number three is a historic reversal of roles between some countries traditionally classified as advanced or industrialized and some countries traditionally classified as emerging or developing. The latter group, especially Latin America, has in the past been characterized by unfortunately procyclical fiscal policy and poor creditworthiness. But in the post-2000 boom, many developing countries achieved stronger budget balances, national saving rates, current account balances, and foreign exchange reserve holdings than in past cycles. As a result, some have been able to reap the rewards of better creditworthiness, as reflected in credit ratings and sovereign spreads, and were better able to respond to the global financial crisis and recession of 2008-09 by easing rather than tightening. Some of these countries have now achieved a fiscal policy that is not only less procyclical than the pattern of their own past histories, but also more countercyclical than that of the advanced countries.

The fiscal regime that has been explored in this paper is among the most wellfocused examples that lie at the intersection of these three trends. For the many other countries that need to make their budgets stronger and less procyclical, Chile's fiscal institutions may offer a useful model.

\footnotetext{
${ }^{58}$ No set of rules or institutions is foolproof against determined efforts to circumvent them. In the United States, for example, politicians who wish to appear fiscally responsible have found legislative tricks for making CBO estimates of future budget deficits falsely appear to diminish and disappear. The Bush Administration routinely left the cost of foreign wars off the budget, treating their continuation as a surprise every year. It also pretended for legal purposes that its extensive tax cuts would expire in the future even though its policy was to renew them when the time came. This recent history makes it hard to propose fiscal rules for the U.S. that would rely on scorekeeping by CBO.
} 


\section{References}

Alesina, Alberto, Filipe Campante, and Guido Tabellini, 2008, "Why is Fiscal Policy Often Procyclical?" Journal of the European Economic Association, 6, no. 5, September, 1006-1036.

Alesina, Alberto, Ricardo Hausmann, Rudolf Hommes, and Ernesto Stein, 1999, "Budget institutions and fiscal performance in Latin America," Journal of Development Economics, Vol. 59, 253-273.

Alesina, Alberto and Roberto Perotti, 1995, "The Political Economy of Budget Deficits," - Staff PapersInternational Monetary Fund, 42, no. 1, March: 1-31.

Alesina, Alberto and Roberto Perotti, 1996, "Fiscal Discipline and the Budget Process ," American Economic Review, Vol. 86, No. 2, Papers and Proceedings (May), pp. 401-407

Aninat, Cristóbal, John Landregan, Patricio Navia, and Joaquín Vial, 2006, "Political Institutions, Policymaking Processes and Policy Outcomes in Chile," Research Network Working Paper R-521," InterAmerican Development Bank, February.

Arezki, Rabah, and Markus Brückner, 2010a, "International Commodity Price Shocks, Democracy, and External Debt,” IMF Working Paper 10/53 (International Monetary Fund: Washington, DC).

Arezki, Rabah, and Markus Brückner, 2010b, "Resource Windfalls and Emerging Market Sovereign Bond Spreads: The Role of Political Institutions" (International Monetary Fund: Washington, DC).

Arezki, Rabah, and Kareem Ismail, 2010, "Boom-Bust Cycle, Asymmetrical Fiscal Response and the Dutch Disease,” IMF WP/10/94 (International Monetary Fund: Washington DC), April.

Ashiya, Mashahiro, 2007, "Forecast Accuracy of the Japanese Government: Its Year-Ahead GDP Forecast is Too Optimistic," Japan and the World Economy 19, no. 1, January, 68-85.

Auerbach, Alan, 1994, “The U.S. Fiscal Problem: Where We are, How We Got Here and Where We're Going,” NBER Macroeconomics Annual 1994, Volume 9, pp. 141-186. NBER WP No. 4709.

Auerbach, Alan, 1999, "On the Performance and Use of Government Revenue Forecasts," National Tax Journal, vol. 52, no. 4, pp. 765-782.

Balagtas, Joseph, and Matthew Holt, 2009, "The Commodity Terms of Trade, Unit Roots and Nonlinear Alternatives: A Smooth Transition Approach," American Journal of Agricultural Economics, Volume 91 Issue 1 , pp. $87-105$.

Beetsma, Roel, and Massimo Giuliodori, 2010, "Fiscal Adjustment to Cyclical Developments in the OECD: An Empirical Analysis Based on Real-Time Data," Oxford Economic Papers, Forthcoming.

Beetsma, Roel, Massimo Giuliodori, and Peter Wierts, 2009, "Planning to Cheat: EU Fiscal Policy in Real Time," Economic Policy 24, 60, 753-804.

Beetsma, Roel, Massimo Giuliodori, Mark Walschot, and Peter Wierts, 2010, "Fifty Years of Fiscal Planning and Implementation in the Netherlands," CEPR Discussion Paper No. 7969, Centre for Economic Policy Research, August.

Brück, Tilman, and Andreas Stephan, 2006, "Do Eurozone Countries Cheat with their Budget Deficit Forecasts?” Kyklos 59, no. 1, Feb., 3-15.

Buchanan, James, 1967, Public Finance in Democratic Process: Fiscal Institutions and Individual Choice (University of North Carolina Press). 
Caballero, Ricardo, 2002, "Coping with Chile's External Vulnerability: A Financial Problem," in Economic Growth: Sources, Trends, and Cycles, edited by Norman Loayza and Raimundo Soto (Central Bank of Chile: Santiago), pp. 377-416.

Calderón, César, Roberto Duncan and Klaus Schmidt-Hebbel, 2010, "Institutions and Cyclical Properties of Macroeconomic Policies in the Global Economy," Documentos de Trabajo 372, Instituto de Economia, Pontificia Universidad Católica de Chile.

Calderón, César, and Klaus Schmidt-Hebbel, 2003, "Macroeconomic Policies and Performance in Latin America," Journal of International Money and Finance 22, no.7, December, pp. 895-923.

Calderón, César, and Klaus Schmidt-Hebbel, 2008, "Business Cycles and Fiscal Policies: The Role of Institutions and Financial Markets," Working Paper 481, Central Bank of Chile.

Cárdenas, Mauricio, Carolina Mejía, and Mauricio Olivera, 2009, "The Political Economy of the Budget Process in Colombia," in Who Decides the Budget, A Political Economy Analysis of the Budget Process in Latin America, edited by Mark Hallerberg, Carlos Scartascini and Ernesto Stein (IDB and David Rockefeller Center for Latin American Studies, Harvard University). Spanish version, "La economía política del proceso presupuestal en Colombia," Working paper No. 31, Fedesarrollo, 2006.

Chang, Chia-Lin, Philip Hans Franses, and Michael McAleer, 2009, "How Accurate are Government Forecasts of Economic Fundamentals: The Case of Taiwan," July.

Corbo, Vittorio, and Stanley Fischer, 1994, "Lessons from the Chilean Stabilization and Recovery," in The Chilean Economy: Policy Lessons and Challenges, edited by Barry Bosworth, Rudiger Dornbusch and Raúl Labán (Brookings Institution: Washington, DC), pp. 29-67.

Cuddington, John, 1989, "Commodity Export Booms in Developing Countries," World Bank Research Observer 4, 143-165.

Cuddington, John, 1992, "Long-Run Trends in 26 Primary Commodity Prices," Journal of Development Economics, 39, 207-27.

Cuddington, John, and Daniel Jerrett, 2008, “Super Cycles in Real Metals Prices?” IMF Staff Papers, 55, December, 541-565.

Cuddington, John, Rodney Ludema and Shamila Jayasuriya, 2007, "Prebisch-Singer Redux," in Natural Resources: Neither Curse Nor Destiny (Stanford Univ. Press, Palo Alto, and World Bank, Washington DC): 103-140.

Cuddington, John, and Carlos M. Urzua, 1989, "Trends and Cycles in the Net Barter Terms of Trade: A New Approach,” Economic Journal 99: 426-42.

Davis, Jeffrey, Rolando Ossowski, James Daniel, and Steven Barnett, 2001, "Oil Funds: Problems Posing as Solutions?" Finance and Development 38, no.4 (IMF, Washington DC).

Davis, Jeffrey, Rolando Ossowski, James Daniel, and Steven Barnett, 2003, "Stabilization and Savings Funds for Nonrenewable Resources: Experience and Fiscal Policy Implications," in J.Davis, R.Ossowski, and A.Fedelino, editors, Fiscal Policy Formulation and Implementation in Oil-Producing Countries (IMF: Washington DC).

Edwards, Sebastián, and Alejandra Cox Edwards, 1991, Monetarism and Liberalization: the Chilean Experiment (University of Chicago Press: Chicago). 
Edwards, Sebastián, and Alejandra Cox Edwards, 2000, "Economic reforms and labour markets: policy issues and lessons from Chile," Economic Policy.

Engel, Eduardo, Mario Marcel y Patrico Meller, 2007, "Meta de Superávit Estructural: elementos para su análisis," Report prepared for the Ministry of Finance.

Engel, Eduardo, Christopher Neilson and Rodrigo Valdés, 2011, "Chile's Structural Balance Rule as Social Policy," Yale University, January 2.

Ffrench-Davis, Ricardo, 2010, Economic Reforms in Chile: From Dictatorship to Democracy," (Palgrave McMillan, NY, $2^{\text {nd }}$ ed.).

Fisher, Ronald A., 1936, "Has Mendel's Work Been Rediscovered?" Annals of Science, Volume 1: 115-37.

Forni, Lorenzo, and Sandro Momigliano, 2004, "Cyclical Sensitivity of Fiscal Policies Based on Real-Time Data", Economic Research Department, Temi di discussione (Economic working papers) no. 540, Bank of Italy.

Frankel, Jeffrey, 1986, "Expectations and Commodity Price Dynamics: The Overshooting Model," American Journal of Agricultural Economics 68, 2, May, 344-48.

Frankel, Jeffrey, 2003, "Republican and Democratic Presidents Have Switched Economic Policies," Milken Institute Review, vol. 5, no. 1, 1st Quarter, pp. 18-25.

Frankel, Jeffrey, 2008a, "The Effect of Monetary Policy on Real Commodity Prices," in Asset Prices and Monetary Policy (University of Chicago Press: Chicago), edited by John Campbell, 291-327.

Frankel, Jeffrey, 2008b, “Snake-Oil Tax Cuts," Briefing Paper 221 (Economic Policy Institute, Washington DC).

Frankel, Jeffrey, 2010, “The Natural Resource Curse: A Survey,” forthcoming in Brenda Shaffer, ed., Export Perils (University of Pennsylvania Press). NBER WP 15836.

Frendreis, John, and Raymond Tatalovich, 2000, "Accuracy and Bias in Macroeconomic Forecasting by the Administration, the CBO, and the Federal Reserve Board," Polity Vol. 32, No. 4 (Summer), pp. 623-632.

Galí, Jordi, and Roberto Perotti, 2003, "Fiscal Policy and Monetary Integration in Europe," Economic Policy 37: 533-572.

Gallego, Francisco, Leonardo Hernández, and Klaus Schmidt-Hebbel, 2002, "Capital Controls in Chile: Were They Effective?" in Leonardo Hernández and Klaus Schmidt-Hebbel, editors, Banking, Financial Integration, and International Crises, chapter 12, pp. 361-412.

Gavin, Michael and Roberto Perotti, 1997, "Fiscal Policy in Latin America," NBER Macroeconomics Annual, Vol. 12, pp. 11-61.

Gavin, Michael, Ricardo Hausmann, Roberto Perotti and Ernesto Talvi, 1996, "Managing Fiscal Policy in Latin America and the Caribbean: Volatility, Procyclicality, and Limited Creditworthiness," InterAmerican Development Bank, RES Working Papers 4032.

Gelb, Alan, 1986, "Adjustment to Windfall Gains: A Comparative Analysis of Oil-Exporting Countries," in "Natural Resources and the Macroeconomy: A Theoretical Framework," in J.Peter Neary and van Sweder Wijnbergen, eds., Natural Resources and the Macroeconomy (MIT Press: Cambridge), 54-93. 
Grilli, Enzo, and Maw Cheng Yang, 1988, "Primary Commodity Prices, Manufactured Goods Prices, and the Terms of Trade of Developing Countries: What the Long Run Shows," World Bank Economic Review 2, no. 1, 1-47.

Hadass, Yael, and Jeffrey Williamson, 2003, "Terms of Trade Shocks and Economic Performance 18701940: Prebisch and Singer Revisited," Economic Development and Cultural Change (University of Chicago Press), vol. 51(3), pages 629-56, April. NBER WP 8188, 2001.

Hartwick, John, 1977, "Intergenerational Equity and the Investing of Rents from Exhaustible Resources," American Economic Review, Vol. 67, No. 5, Dec., pp. 972-974.

Harvey, David, Neil Kellard, Jakob Madsen, and Mark Wohar, 2010, "The Prebisch-Singer Hypothesis: Four Centuries of Evidence," Review of Economics and Statistics, 92, no. 2, May, 367-377.

Hotelling, Harold, 1931, “The Economics of Exhaustible Resources,” Journal of Political Economy, 39, no. 2, 137-75.

Ilzetski, Ethan, and Carlos Vegh, 2008, "Procyclical Fiscal Policy in Developing Countries: Truth or Fiction?” NBER WP no. 14191.

Jonung, Lars, and Martin Larch, 2006, "Improving Fiscal Policy in the EU: The Case for Independent Forecasts," Economic Policy, 21(47), pp. 491-534.

Kaminsky, Graciela, Carmen Reinhart, and Carlos Vegh, 2005, "When It Rains, It Pours: Procyclical Capital Flows and Macroeconomic Policies," NBER Macroeconomics Annual 2004, Vol. 19, pages 11-82.

Kellard, Neil, and Mark Wohar, 2006, "On the prevalence of trends in primary commodity prices ," Journal of Development Economics, 79, no.1, February, 146-167.

Larrain, Felipe, and Francisco Parro, 2006, “Chile Menos Volatil,” Central Bank of Chile, May.

Larrain, Felipe, Jeffrey Sachs, and Andrew Warner, 2000, "A Structural Analysis of Chile's Long-Term Growth: History, Prospects and Policy Implications," Paper prepared for the Government of Chile (Earth Institute: NY), January.

Lefort, Guillermo, 2006, "Política Fiscal con Meta Estructural en la Experiencia Chilena," ["Structural Fiscal Policies to Target in the Chilean Experience"] the Group of Latin American Debt Management Specialists, IDB, Cartagena, Colombia.

Madrid-Aris, Manuel, and Marcelo Villena, 2005, "The Commoditization of the Chilean Economy: Some Stylized Facts About its Economy," Universidad Santa Maria, Chile.

Marcel, Mario, Marcelo Tokman, Rodrigo Valdés, and Paula Benavides, 2001, "Structural Budget Balance: Methodology and Estimation for the Chilean Central Government 1987-2001," Series of Studies on Public Finance, Ministry of Finance, Chile. At http://www.dipres.cl/572/propertyvalue-15408.html.

Marinheiro, Carlos. 2008, "The Stability and Growth Pact, Fiscal Policy Institutions and Stabilization in Europe," International Economics and Economic Policy, Springer, vol. 5(1), July, pp. 189-207.

Marinheiro, Carlos. 2010, "Fiscal Sustainability and the Accuracy of Macroeconomic Forecasts: Do Supranational Forecasts Rather than Government Forecasts Make a Difference?," GEMF Working Papers 2010-07, Faculdade de Economia, Universidade de Coimbra. Forthcoming, International Journal of Sustainable Economy. 
McNab, Robert M., Mark Rider, Kent Wall, 2007, "Are Errors in Official US Budget Receipts Forecasts Just Noise?” Andrew Young School Research Paper Series Working Paper 07-22, April.

McNees, Stephen, 1995, “An Assessment of the "Official” Economic Forecasts," New England Economic Review.

Medas, Paolo, and Daria Zakharova, 2009, "Primer on Fiscal Analysis in Oil-Producing Countries," IMF working paper 56, March.

Medina, Juan Pablo, and Claudio Soto, 2007, "Copper Price, Fiscal Policy and Business Cycle in Chile," Banco Central de Chile Documentos de Trabajo, Central Bank of Chile Working Papers $N^{\circ} 458$ Diciembre.

Mendoza, Enrique G. and P. Marcelo Oviedo, 2006, "Fiscal Policy and Macroeconomic Uncertainty in Developing Countries: The Tale of the Tormented Insurer," NBER Working Paper No. 12586, October.

Mühleisen, Martin, Stephan Danninger, David Hauner, Kornélia Krajnyák, and Bennett Sutton, 2005, "How Do Canadian Budget Forecasts Compare With Those of Other Industrial Countries?" IMF Working Papers 05/66, April.

Neut, Alejandro, and Andres Velasco, 2003, “Tough Policies, Incredible Policies?” NBER Working Paper No. 9932, September.

O'Neill, Tim, 2005, Review of Canadian Fiscal Forecasting: Processes and Systems, Department of Finance, Canada, June. http://www.fin.gc.ca/toc/2005/oneil_-eng.asp

Ossowski, Rolando, Mauricio Villafuerte, Paulo Medas, and Theo Thomas, 2008, "Managing the Oil Revenue Boom: The Role of Fiscal Institutions," Occasional Paper No. 260 (International Monetary Fund: Washington, DC).

Perry, Guillermo, 2003, "Can Fiscal Rules Help Reduce Macroeconomic Volatility in the Latin America and Caribbean Region?” World Bank Policy Research Working Paper No. 3080, June.

Perry, Guillermo, 2009, Beyond Lending How Multilateral Banks Can Help Developing Countries Manage Volatility (Center for Global Development: Washington DC).

Persson, Torsten, and Guido Tabellini, 2004, "Constitutional Rules and Fiscal Policy Outcomes," American Economic Review, 94, Number 1, March, pp. 25-45.

Pindyck, Robert, 1999, “The Long-Run Evolution of Energy Prices,” The Energy Journal; 20, 2.

Poterba, James, 1997, “Do Budget Rules Work?” in A.Auerbach ed., Fiscal Policy: Lessons From

Empirical Research (Cambridge: MIT Press). pp.53-86.

Poterba, James, and Jürgen von Hagen, 1999, Editors, Fiscal Institutions and Fiscal Performance (University of Chicago Press).

Reinhart, Carmen, and Peter Wickham, 1994, "Commodity Prices: Cyclical Weakness or Secular Decline?" IMF Staff Papers 41, June.

Rodriguez Cabello, Jorge, Carla Tokman Ramos, and Alejandra Vega Carvallo, 2007, "Structural Balance Policy in Chile," Studies in Public Finance, Ministry of Finance, Government of Chile, December [English translation of Study no. 7, December 2006.] 
Santiso, Carlos, 2005, "Budget Institutions and Fiscal Responsibility: Parliaments and the Political Economy of the Budget Process in Latin America," World Bank Institute.

Sinnott, Emily, 2009, "Commodity Prices and Fiscal Policy in Latin America and the Caribbean," presented at workshop on Myths and Realities of Commodity Dependence: Policy Challenges and Opportunities for Latin America and the Caribbean, World Bank, Sept. 17-18, 2009.

Solow, Robert, 1986, "On the Intergenerational Allocation of Natural Resources," The Scandinavian Journal of Economics, Vol. 88, No. 1, pp. 141-149.

Stein, Ernesto, Ernesto Talvi, and Alejandro Grisanti, 1999, "Institutional Arrangements and Fiscal Performance: The Latin American Experience," in James Poterba and Jürgen von Hagen, editors, Fiscal Institutions and Fiscal Performance (University of Chicago Press).

Strauch, Rolf, Mark Hallerberg and Jürgen von Hagen. 2009. "How Forms of Fiscal Governance Affect Fiscal Performance," In Fiscal Governance in Europe, ed. M. Hallerberg, R. Strauch and J. v. Hagen (Cambridge University Press). Revised version of Von Hagen, Hallerberg, and Strauch, 2004, "Budgetary Forecasts in Europe - The Track Record of Stability and Convergence Programmes", ECB WP No. 30.

Talvi, Ernesto, and Carlos Vegh, 2005, “Tax Base Variability and Procyclicality of Fiscal Policy," Journal of Development Economics 78, no. 1, 156-190.

Tornell, Aaron, and Philip Lane, 1999, "The Voracity Effect," American Economic Review 89, no. 1, March: 22-46.

Velasco, Andrés, 1994, “The State and Economic Policy: Chile 1952-92," in The Chilean Economy: Policy Lessons and Challenges, edited by Barry Bosworth, Rudiger Dornbusch and Raúl Labán (Brookings Institution: Washington, DC), pp. 379-410.

Velasco, Andrés, Luis Felipe Céspedes, Jorge Rodríguez Cabello, and Alberto Arenas de Mesa, 2007, "Compromisos Fiscales y la Meta de Superávit Estructural" Serie de Estudios de Finanzas Públicas N9, DIPRES, Ministerio de Hacienda, Chile, Mayo. At http://www.dipres.gov.c1/572/articles-21645_doc_pdf.pdf

Velasco, Andrés, Alberto Arenas de Mesa, Jorge Rodríguez Cabello, Michael Jorratt de Luis, and Cristóbal Gamboni, 2010, "The Structural Balance Approach to Fiscal Policy in Chile: Results, Methodology and Application to the Period 2006 - 2009," DIPRES, Ministerio de Hacienda, Chile, Feb.

At http://www.dipres.gov.cl/572/articles-60584_doc_pdf.pdf .

von Hagen, Jürgen, and Ian Harden, 1995, "Budget Processes and Commitment to Fiscal Discipline," European Economic Review, Volume 39, Issues 3-4, April, Pages 771-779.

Wyplosz, Charles, 2005, “Fiscal Policy: Institutions versus Rules," National Institute Economic Review. Also CEPR Discussion Papers no. 3238. 
Appendix Figure 1: Price of copper in real terms, 30-year sample

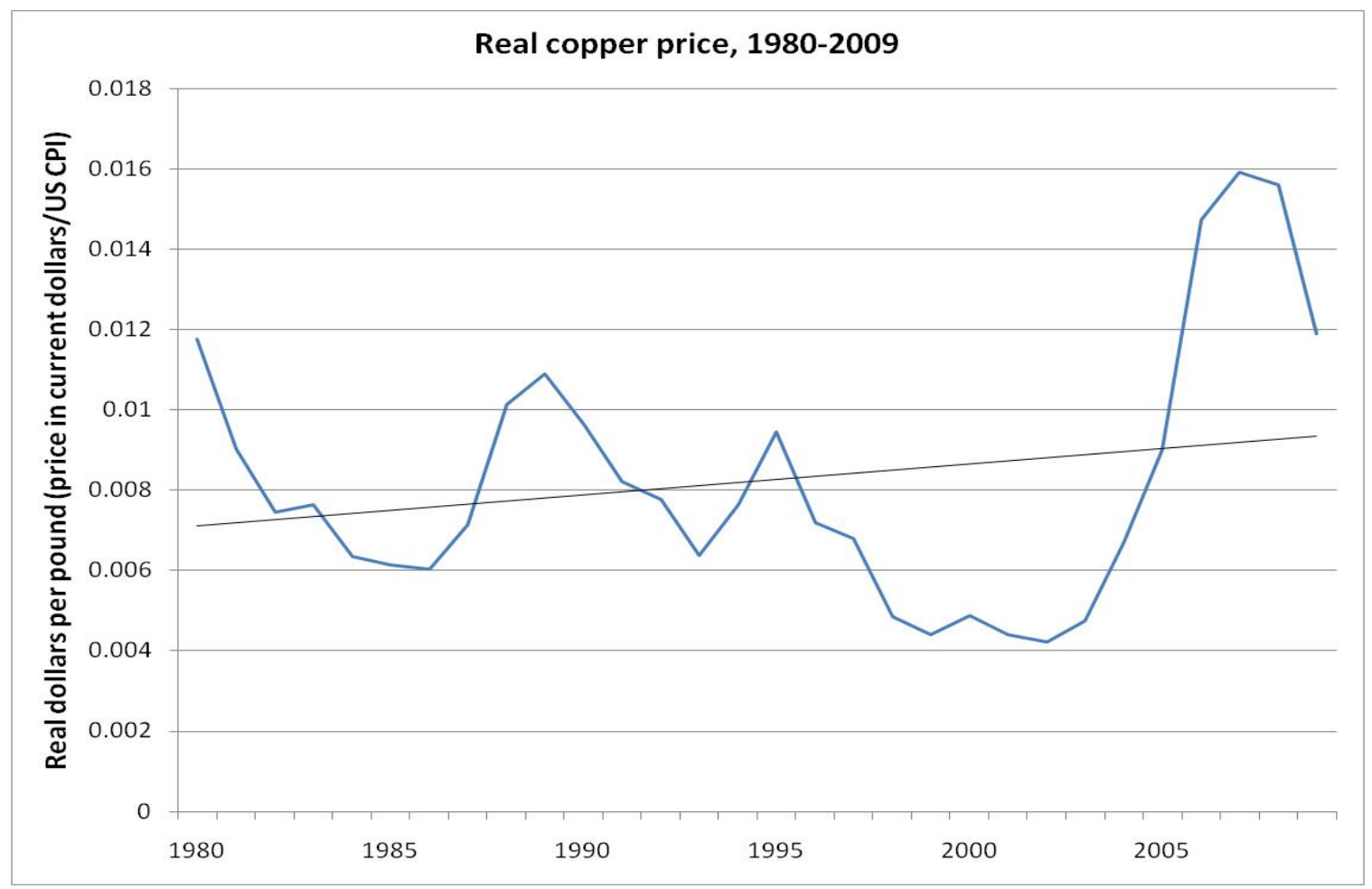

\begin{tabular}{|c|c|c|c|c|c|}
\hline \multicolumn{6}{|c|}{$\begin{array}{c}\text { Appendix Table 1: } \begin{array}{c}\text { Errors in forecasting budget surplus (official forecast - actual) } \\
\text { expressed as \% of GDP }\end{array} \\
\end{array}$} \\
\hline & & $\begin{array}{l}\text { Actual fiscal } \\
\text { balance }\end{array}$ & $\begin{array}{l}\text { One year ahead } \\
\text { budget forecast } \\
\text { error }\end{array}$ & $\begin{array}{l}\text { Two year } \\
\text { ahead budget } \\
\text { forecast error }\end{array}$ & $\begin{array}{l}\text { Three year } \\
\text { ahead budget } \\
\text { forecast error }\end{array}$ \\
\hline Australia & Mean & -0.2 & -0.2 & -0.2 & 1.2 \\
\hline 1985-2009 & Min & -2.7 & -1.6 & -1.4 & -0.9 \\
\hline & Max & 1.7 & 4.0 & 3.3 & 3.2 \\
\hline & Obs. & 26 & 25 & 14 & 2 \\
\hline Austria & Mean & -1.8 & 0.3 & 0.7 & 0.9 \\
\hline 1999-2009 & Min & -3.9 & -0.6 & -1.3 & -1.3 \\
\hline & Max & -0.2 & 3.2 & 3.3 & 4.1 \\
\hline & Obs. & 13 & 11 & 10 & 9 \\
\hline Belgium & Mean & -1.0 & 0.2 & 1.0 & 1.3 \\
\hline 1999-2009 & Min & -5.9 & -1.1 & -1.1 & -1.0 \\
\hline & Max & 0.3 & 2.4 & 6.2 & 6.6 \\
\hline & Obs. & 13 & 11 & 10 & 9 \\
\hline Canada & Mean & -2.1 & -0.9 & -0.7 & NA \\
\hline
\end{tabular}




\begin{tabular}{|c|c|c|c|c|c|}
\hline 1985-2008 & Min & -8.6 & -2.6 & -2.5 & NA \\
\hline & Max & 1.3 & 0.5 & 1.7 & NA \\
\hline & Obs. & 26 & 23 & 20 & 0 \\
\hline Chile & Mean & 2.2 & -1.4 & NA & NA \\
\hline \multirow[t]{3}{*}{ 1977-2009 } & Min & -5.5 & -8.3 & NA & NA \\
\hline & Max & 8.9 & 8.1 & NA & NA \\
\hline & Obs. & 33 & 33 & 0 & 0 \\
\hline Cyprus & Mean & -28 & 02 & 04 & 01 \\
\hline \multirow[t]{3}{*}{ 2005-2009 } & Min & -6.5 & -4.9 & -5.1 & -4.8 \\
\hline & Max & 3.3 & 5.3 & 6.6 & 5.7 \\
\hline & Obs. & 12 & 5 & 4 & 3 \\
\hline Czech Republic & Mean & -42 & -01 & -03 & 04 \\
\hline \multirow[t]{3}{*}{ 2005-2009 } & Min & -6.8 & -2.4 & -1.9 & -1.7 \\
\hline & Max & -1.6 & 5.0 & 3.6 & 3.6 \\
\hline & Obs. & 13 & 5 & 4 & 3 \\
\hline Denmark & Mean & 1.6 & 0.1 & 0.2 & 0.1 \\
\hline \multirow[t]{3}{*}{ 1999-2008 } & Min & -3.0 & -2.8 & -3.1 & -2.8 \\
\hline & Max & 4.8 & 3.0 & 5.0 & 4.8 \\
\hline & Obs. & 13 & 11 & 10 & 9 \\
\hline Estonia & Mean & 0.3 & -0.3 & 0.4 & 1.4 \\
\hline \multirow[t]{3}{*}{ 2005-2009 } & Min & -3.5 & -3.3 & -3.4 & -2.8 \\
\hline & Max & 3.4 & 4.1 & 4.1 & 4.2 \\
\hline & Obs. & 13 & 5 & 4 & 3 \\
\hline Finland & Mean & 2.8 & -0.5 & -0.8 & -0.3 \\
\hline \multirow{3}{*}{ 1999-2009 } & Min & -2.2 & -2.5 & -4.7 & -3.1 \\
\hline & Max & 6.9 & 4.3 & 5.8 & 4.9 \\
\hline & Obs. & 13 & 11 & 10 & 9 \\
\hline France & Mean & -3.5 & 0.6 & 1.5 & 2.2 \\
\hline \multirow{3}{*}{ 1996-2009 } & Min & -7.9 & -0.5 & -0.4 & 0.1 \\
\hline & Max & -1.5 & 4.0 & 6.2 & 7.0 \\
\hline & Obs. & 16 & 14 & 10 & 9 \\
\hline Germany & Mean & -3.0 & 1.0 & 1.4 & 1.3 \\
\hline \multirow[t]{3}{*}{ 1991-2009 } & Min & -4.8 & -1.7 & -2.5 & -2.0 \\
\hline & Max & 0.0 & 3.5 & 3.4 & 3.8 \\
\hline & Obs. & 19 & 19 & 18 & 9 \\
\hline Greece & Mean & -5.5 & 4.3 & 5.4 & 6.0 \\
\hline \multirow[t]{3}{*}{ 2000-2009 } & Min & -12.7 & 0.3 & 0.1 & 0.9 \\
\hline & Max & -2.9 & 9.0 & 11.9 & 11.5 \\
\hline & Obs. & 13 & 10 & 9 & 8 \\
\hline Hungary & Mean & -6.1 & 1.7 & 2.2 & 1.9 \\
\hline \multirow[t]{3}{*}{ 2005-2009 } & Min & -9.3 & -1.3 & -0.5 & 0.7 \\
\hline & Max & -3.0 & 4.6 & 6.2 & 3.1 \\
\hline & Obs. & 13 & 5 & 4 & 3 \\
\hline
\end{tabular}




\begin{tabular}{|c|c|c|c|c|c|}
\hline Ireland & Mean & 0.0 & 0.4 & 1.0 & 1.9 \\
\hline \multirow[t]{3}{*}{ 1999-2009 } & Min & -11.7 & -3.6 & -3.6 & -4.1 \\
\hline & Max & 4.7 & 6.3 & 10.6 & 12.3 \\
\hline & Obs. & 13 & 11 & 10 & 9 \\
\hline Italy & Mean & -7.9 & 1.1 & 1.6 & 2.6 \\
\hline \multirow[t]{3}{*}{ 1990-2009 } & Min & -18.1 & -3.8 & -3.5 & 0.5 \\
\hline & Max & -1.8 & 5.8 & 5.2 & 4.2 \\
\hline & Obs. & 25 & 20 & 19 & 9 \\
\hline Latvia & Mean & -2.1 & 1.5 & 2.9 & 3.7 \\
\hline \multirow[t]{3}{*}{$2005-2009$} & Min & -10.0 & -1.3 & -1.4 & -1.4 \\
\hline & Max & 1.4 & 6.5 & 11.0 & 9.6 \\
\hline & Obs. & 13 & 5 & 4 & 3 \\
\hline Lithuania & Mean & -3.4 & 1.4 & 2.7 & 3.7 \\
\hline \multirow[t]{3}{*}{$2005-2009$} & Min & -11.9 & -2.0 & -1.3 & -0.3 \\
\hline & Max & -0.5 & 7.0 & 9.3 & 9.1 \\
\hline & Obs. & 13 & 5 & 4 & 3 \\
\hline Luxemburg & Mean & 2.3 & -1.7 & -1.4 & -0.7 \\
\hline \multirow[t]{3}{*}{ 1999-2009 } & Min & -1.2 & -4.8 & -4.8 & -4.8 \\
\hline & Max & 6.1 & 2.2 & 2.6 & 4.6 \\
\hline & Obs. & 13 & 11 & 10 & 9 \\
\hline Malta & Mean & -5.7 & 0.9 & 1.8 & 2.6 \\
\hline \multirow[t]{3}{*}{ 2005-2009 } & Min & -9.9 & -0.7 & -0.5 & 0.4 \\
\hline & Max & -1.8 & 3.5 & 3.8 & 3.9 \\
\hline & Obs. & 13 & 5 & 4 & 3 \\
\hline Mexico & Mean & -0.6 & 0.1 & NA & $\mathrm{NA}$ \\
\hline \multirow[t]{3}{*}{ 1995-2009 } & Min & -2.3 & -0.1 & NA & NA \\
\hline & Max & 0.1 & 0.6 & NA & NA \\
\hline & Obs. & 15 & 15 & 0 & 0 \\
\hline Netherlands & Mean & -2.7 & 0.6 & 0.4 & 0.7 \\
\hline \multirow[t]{3}{*}{ 1995-2009 } & Min & -11.0 & -2.3 & -2.6 & -2.3 \\
\hline & Max & 1.3 & 7.1 & 5.5 & 5.8 \\
\hline & Obs. & 17 & 15 & 10 & 9 \\
\hline New Zealand & Mean & 1.9 & -0.1 & -0.4 & -0.8 \\
\hline \multirow[t]{3}{*}{$1995-2008$} & Min & -0.9 & -4.2 & -3.9 & -0.8 \\
\hline & Max & 7.3 & 2.9 & 3.9 & -0.8 \\
\hline & Obs. & 18 & 13 & 12 & 1 \\
\hline Poland & Mean & -4.4 & 1.6 & 2.1 & 2.7 \\
\hline \multirow[t]{3}{*}{$2005-2009$} & Min & -7.2 & 0.4 & -0.2 & -0.2 \\
\hline & Max & -2.0 & 4.7 & 5.2 & 6.6 \\
\hline & Obs. & 13 & 5 & 4 & 3 \\
\hline Portugal & Mean & -3.9 & 1.4 & 2.3 & 3.1 \\
\hline 1999-2009 & Min & -9.3 & -1.0 & -1.0 & 0.1 \\
\hline
\end{tabular}




\begin{tabular}{|c|c|c|c|c|c|}
\hline & Max & -2.7 & 5.4 & 7.8 & 7.8 \\
\hline & Obs. & 13 & 11 & 10 & 9 \\
\hline Slovakia & Mean & -5.2 & 0.5 & 1.4 & 1.9 \\
\hline \multirow[t]{3}{*}{ 2005-2009 } & Min & -12.2 & -0.7 & -0.1 & 0.3 \\
\hline & Max & -2.2 & 3.3 & 4.5 & 4.4 \\
\hline & Obs. & 13 & 5 & 4 & 3 \\
\hline Slovenia & Mean & -2.6 & -0.2 & 0.9 & 1.5 \\
\hline \multirow[t]{3}{*}{ 2005-2009 } & Min & -5.7 & -1.4 & -1.3 & -1.0 \\
\hline & Max & -0.1 & 0.9 & 5.1 & 4.7 \\
\hline & Obs. & 13 & 5 & 4 & 3 \\
\hline South Africa & Mean & -1.6 & -0.3 & -1.3 & -1.5 \\
\hline \multirow[t]{3}{*}{ 1998-2008 } & Min & -5.2 & -2.8 & -4.0 & -4.4 \\
\hline & Max & 1.7 & 5.6 & 0.9 & 0.2 \\
\hline & Obs. & 13 & 11 & 10 & 9 \\
\hline Spain & Mean & -1.6 & 0.9 & 1.5 & 1.6 \\
\hline \multirow[t]{3}{*}{ 1999-2009 } & Min & -11.4 & -1.2 & -1.6 & -1.8 \\
\hline & Max & 2.2 & 5.6 & 12.6 & 12.3 \\
\hline & Obs. & 13 & 11 & 10 & 9 \\
\hline Sweden & Mean & 0.8 & 0.4 & 0.7 & 1.4 \\
\hline \multirow[t]{3}{*}{ 1998-2009 } & Min & -2.2 & -1.7 & -2.3 & -2.5 \\
\hline & Max & 3.8 & 3.5 & 5.3 & 5.3 \\
\hline & Obs. & 14 & 12 & 11 & 9 \\
\hline Switzerland & Mean & -0.4 & -0.2 & -0.2 & NA \\
\hline \multirow[t]{3}{*}{ 1990-2003 } & Min & -2.2 & -2.9 & -2.3 & NA \\
\hline & Max & 0.8 & 1.4 & 1.0 & NA \\
\hline & Obs. & 16 & 14 & 13 & 0 \\
\hline United Kingdom & Mean & -3.0 & 0.8 & 1.8 & 2.8 \\
\hline \multirow[t]{3}{*}{ 1997-2009 } & Min & -12.6 & -1.4 & -1.9 & -0.7 \\
\hline & Max & 2.7 & 4.5 & 10.2 & 10.9 \\
\hline & Obs. & 25 & 13 & 11 & 9 \\
\hline United States & Mean & -2.7 & 0.4 & 1.0 & 3.1 \\
\hline \multirow[t]{3}{*}{ 1986-2009 } & Min & -9.9 & -2.2 & -3.1 & -0.6 \\
\hline & $\operatorname{Max}$ & 2.6 & 7.2 & 8.7 & 8.5 \\
\hline & Obs. & 26 & 24 & 23 & 3 \\
\hline \multirow[t]{4}{*}{ Total } & Mean & -1.9 & 0.2 & 0.8 & 1.5 \\
\hline & Min & -18.1 & -8.3 & -5.1 & -4.8 \\
\hline & Max & 8.9 & 9.0 & 12.6 & 12.3 \\
\hline & Obs. & 535 & 399 & 300 & 179 \\
\hline
\end{tabular}

Years are those that we have data for the one year ahead budget forecast error. 


\begin{tabular}{|c|c|c|c|c|c|}
\hline \multicolumn{6}{|c|}{$\begin{array}{l}\text { Appendix Table 2: Errors in forecasting GDP growth rate } \\
\text { (official forecast - actual) }\end{array}$} \\
\hline & & $\begin{array}{l}\text { Actual GDP } \\
\text { growth rate }\end{array}$ & $\begin{array}{l}\text { One year ahead } \\
\text { GDP growth } \\
\text { rate forecast } \\
\text { error }\end{array}$ & $\begin{array}{l}\text { Two year } \\
\text { ahead GDP } \\
\text { growth rate } \\
\text { forecast error }\end{array}$ & $\begin{array}{l}\text { Three year } \\
\text { ahead GDP } \\
\text { growth rate } \\
\text { forecast error }\end{array}$ \\
\hline Australia & Mean & 3.1 & 0.2 & 0.8 & NA \\
\hline \multirow[t]{3}{*}{ 1987-2009 } & Min & -0.8 & -2.0 & 0.4 & NA \\
\hline & Max & 4.6 & 2.8 & 1.1 & NA \\
\hline & Obs. & 24 & 23 & 2 & 0 \\
\hline Austria & Mean & 1.9 & 0.1 & 0.9 & 1.0 \\
\hline \multirow[t]{3}{*}{ 1999-2009 } & Min & -3.4 & -1.5 & -1.0 & -1.2 \\
\hline & $\operatorname{Max}$ & 3.6 & 2.0 & 5.9 & 5.9 \\
\hline & Obs. & 13 & 11 & 10 & 9 \\
\hline Belgium & Mean & 1.8 & 0.0 & 0.9 & 1.1 \\
\hline \multirow[t]{3}{*}{ 1999-2009 } & Min & -3.1 & -1.2 & -1.4 & -0.6 \\
\hline & Max & 3.7 & 1.7 & 5.1 & 5.3 \\
\hline & Obs. & 13 & 11 & 10 & 9 \\
\hline Canada & Mean & 29 & -03 & 04 & $\mathrm{NA}$ \\
\hline \multirow[t]{3}{*}{ 1985-2003 } & Min & -1.7 & -3.3 & -2.6 & NA \\
\hline & Max & 5.1 & 2.0 & 4.7 & NA \\
\hline & Obs. & 21 & 18 & 17 & 0 \\
\hline Chile & Mean & 4.9 & -0.8 & NA & NA \\
\hline \multirow[t]{3}{*}{ 1981, 1985-2008 } & Min & -10.3 & -7.3 & NA & NA \\
\hline & Max & 12.3 & 4.6 & NA & NA \\
\hline & Obs. & 28 & 25 & 0 & 0 \\
\hline Cyprus & Mean & 33 & 07 & 16 & 23 \\
\hline \multirow[t]{3}{*}{ 2005-2009 } & Min & -1.7 & -0.5 & 0.1 & 0.4 \\
\hline & Max & 5.9 & 3.8 & 5.7 & 5.8 \\
\hline & Obs. & 13 & 5 & 4 & 3 \\
\hline & & & & & \\
\hline Czech Republic & Mean & 2.6 & 0.8 & 1.7 & 2.6 \\
\hline \multirow[t]{3}{*}{ 2005-2009 } & Min & -4.0 & -2.8 & -2.5 & -2.7 \\
\hline & Max & 6.5 & 7.7 & 9.0 & 8.8 \\
\hline & Obs. & 13 & 5 & 4 & 3 \\
\hline Denmark & Mean & 1.4 & 0.5 & 0.6 & 1.0 \\
\hline \multirow[t]{3}{*}{ 1999-2009 } & Min & -4.3 & -1.9 & -2.6 & -2.0 \\
\hline & Max & 3.9 & 4.1 & 5.4 & 5.0 \\
\hline & Obs. & 13 & 11 & 10 & 9 \\
\hline Estonia & Mean & 52 & 24 & 6.5 & 103 \\
\hline \multirow[t]{3}{*}{ 2005-2009 } & Min & -14.5 & -4.6 & -5.2 & -1.1 \\
\hline & $\operatorname{Max}$ & 11.2 & 11.0 & 20.6 & 22.1 \\
\hline & Obs. & 13 & 5 & 4 & 3 \\
\hline Finland & Mean & 2.7 & 0.7 & 0.7 & 0.9 \\
\hline
\end{tabular}




\begin{tabular}{|c|c|c|c|c|c|}
\hline 1999-2009 & Min & -7.6 & -1.7 & -2.5 & -2.5 \\
\hline & Max & 6.1 & 8.2 & 10.6 & 10.2 \\
\hline & Obs. & 13 & 11 & 10 & 9 \\
\hline France & Mean & 1.7 & 0.6 & 1.0 & 1.3 \\
\hline \multirow[t]{3}{*}{ 1998-2009 } & Min & -2.3 & -0.9 & -1.4 & 0.0 \\
\hline & Max & 3.9 & 2.7 & 4.8 & 4.6 \\
\hline & Obs. & 14 & 12 & 10 & 9 \\
\hline Germany & Mean & 1.4 & 0.9 & 1.2 & 1.7 \\
\hline \multirow[t]{3}{*}{ 1992-2009 } & Min & -5.0 & -1.5 & -1.5 & -0.7 \\
\hline & Max & 3.9 & 5.2 & 6.5 & 6.8 \\
\hline & Obs. & 20 & 18 & 18 & 9 \\
\hline Greece & Mean & 3.5 & 0.2 & 0.7 & 0.9 \\
\hline \multirow[t]{3}{*}{ 2000-2009 } & Min & -1.2 & -1.2 & -1.0 & -0.6 \\
\hline & Max & 5.0 & 2.3 & 5.2 & 5.3 \\
\hline & Obs. & 13 & 10 & 9 & 8 \\
\hline Hungary & Mean & 3.0 & 1.8 & 4.0 & 5.8 \\
\hline \multirow[t]{3}{*}{ 2005-2009 } & Min & -6.7 & -0.1 & 0.3 & 3.0 \\
\hline & Max & 5.2 & 5.8 & 10.7 & 10.9 \\
\hline & Obs. & 13 & 5 & 4 & 3 \\
\hline Ireland & Mean & 5.4 & 0.0 & 1.2 & 1.7 \\
\hline \multirow[t]{3}{*}{ 1999-2009 } & Min & -7.5 & -3.7 & -2.9 & -1.0 \\
\hline & $\operatorname{Max}$ & 11.4 & 6.7 & 11.0 & 11.5 \\
\hline & Obs. & 13 & 11 & 10 & 9 \\
\hline Italy & Mean & 1.7 & 0.7 & 1.3 & 2.3 \\
\hline \multirow[t]{3}{*}{ 1991-2009 } & Min & -4.8 & -1.4 & -0.9 & 0.7 \\
\hline & $\operatorname{Max}$ & 4.8 & 2.8 & 6.4 & 6.4 \\
\hline & Obs. & 25 & 18 & 17 & 9 \\
\hline Latvia & Mean & 4.9 & 3.2 & 6.9 & 11.2 \\
\hline \multirow[t]{3}{*}{$2005-2009$} & Min & -18.0 & -5.4 & -6.4 & -3.6 \\
\hline & Max & 12.9 & 13.0 & 25.0 & 25.5 \\
\hline & Obs. & 13 & 5 & 4 & 3 \\
\hline Lithuania & Mean & 4.8 & 1.5 & 4.3 & 7.0 \\
\hline \multirow[t]{3}{*}{ 2005-2009 } & Min & -15.0 & -2.3 & -3.3 & -2.6 \\
\hline & Max & 10.4 & 10.2 & 19.5 & 19.5 \\
\hline & Obs. & 13 & 5 & 4 & 3 \\
\hline Luxemburg & Mean & 4.3 & -0.1 & 0.9 & 1.6 \\
\hline \multirow[t]{3}{*}{ 1999-2009 } & Min & -3.9 & -5.2 & -4.7 & -2.3 \\
\hline & Max & 8.6 & 6.9 & 8.9 & 7.9 \\
\hline & Obs. & 13 & 11 & 10 & 9 \\
\hline Malta & Mean & 2.5 & -0.3 & -0.1 & 0.8 \\
\hline \multirow[t]{3}{*}{ 2005-2009 } & Min & -2.5 & -3.8 & -3.5 & -2.5 \\
\hline & Max & 8.1 & 4.2 & 5.2 & 5.1 \\
\hline & Obs. & 13 & 5 & 4 & 3 \\
\hline
\end{tabular}




\begin{tabular}{|c|c|c|c|c|c|}
\hline Mexico & Mean & 1.5 & 1.7 & NA & NA \\
\hline \multirow{3}{*}{ 2003-2009 } & Min & -6.5 & -1.2 & NA & NA \\
\hline & Max & 4.8 & 9.5 & NA & NA \\
\hline & Obs. & 8 & 7 & 0 & 0 \\
\hline Netherlands & Mean & 21 & 02 & 08 & 11 \\
\hline \multirow[t]{3}{*}{ 1995-2009 } & Min & -4.0 & -2.5 & -1.8 & -1.0 \\
\hline & Max & 4.7 & 5.3 & 5.8 & 5.8 \\
\hline & Obs. & 17 & 15 & 10 & 9 \\
\hline New Zealand & Mean & 2.8 & -0.3 & 0.3 & 0.4 \\
\hline \multirow[t]{3}{*}{ 1998-2008 } & Min & 0.0 & -1.7 & -1.1 & 0.4 \\
\hline & Max & 4.6 & 2.7 & 4.2 & 0.4 \\
\hline & Obs. & 13 & 11 & 10 & 1 \\
\hline Poland & Mean & 4.3 & 0.1 & 0.0 & 1.0 \\
\hline \multirow[t]{3}{*}{ 2005-2009 } & Min & 1.2 & -1.9 & -1.9 & -0.9 \\
\hline & Max & 7.1 & 2.0 & 3.3 & 3.9 \\
\hline & Obs. & 13 & 5 & 4 & 3 \\
\hline Portugal & Mean & 1.7 & 0.7 & 1.9 & 2.5 \\
\hline \multirow[t]{3}{*}{ 1999-2009 } & Min & -2.7 & -0.6 & -0.7 & 0.9 \\
\hline & Max & 4.8 & 2.2 & 5.5 & 5.7 \\
\hline & Obs. & 13 & 11 & 10 & 9 \\
\hline Slovakia & Mean & 4.2 & 0.0 & 0.7 & 1.7 \\
\hline \multirow[t]{3}{*}{ 2005-2009 } & Min & -5.7 & -3.3 & -4.3 & -5.0 \\
\hline & Max & 10.4 & 8.1 & 11.5 & 10.8 \\
\hline & Obs. & 13 & 5 & 4 & 3 \\
\hline Slovenia & Mean & 3.4 & 0.1 & 2.1 & 3.2 \\
\hline \multirow[t]{3}{*}{ 2005-2009 } & Min & -7.3 & -1.8 & -2.1 & -2.1 \\
\hline & Max & 6.1 & 3.3 & 11.4 & 11.4 \\
\hline & Obs. & 13 & 5 & 4 & 3 \\
\hline South Africa & Mean & 3.2 & 0.2 & 0.1 & 0.1 \\
\hline \multirow[t]{3}{*}{ 1998-2008 } & Min & 0.4 & -1.5 & -1.7 & -1.6 \\
\hline & Max & 5.6 & 2.6 & 2.7 & 2.8 \\
\hline & Obs. & 13 & 11 & 10 & 8 \\
\hline Spain & Mean & 3.0 & 0.0 & 0.5 & 0.8 \\
\hline \multirow[t]{3}{*}{ 1999-2009 } & Min & -3.6 & -1.4 & -1.8 & -0.9 \\
\hline & $\operatorname{Max}$ & 5.1 & 2.2 & 6.6 & 6.9 \\
\hline & Obs. & 13 & 11 & 10 & 9 \\
\hline Sweden & Mean & 2.2 & 0.4 & 0.4 & 0.7 \\
\hline \multirow[t]{3}{*}{ 1998-2009 } & Min & -5.2 & -2.4 & -2.2 & -1.8 \\
\hline & Max & 4.6 & 6.5 & 7.7 & 7.9 \\
\hline & Obs. & 14 & 12 & 11 & 9 \\
\hline Switzerland & Mean & 1.1 & 0.9 & 1.1 & NA \\
\hline 1990-2003 & Min & -0.7 & -1.6 & -1.4 & $\mathrm{NA}$ \\
\hline
\end{tabular}




\begin{tabular}{|l|l|r|r|r|r|}
\hline & Max & 3.4 & 2.7 & 2.7 & NA \\
\hline & Obs. & 16 & 14 & 13 & 0 \\
\hline & & & & & 0.9 \\
\hline United Kingdom & Mean & 2.1 & 0.0 & 0.7 & -1.0 \\
\hline $\mathbf{1 9 9 8 - 2 0 0 9}$ & Min & -4.8 & -2.0 & -1.5 & 7.3 \\
\hline & Max & 3.8 & 3.8 & 7.6 & 9 \\
\hline & Obs. & 13 & 12 & 11 & 3.8 \\
\hline & & & & & 1.9 \\
\hline United States & Mean & 2.7 & 0.5 & 0.6 & 5.6 \\
\hline $\mathbf{1 9 8 5 - 2 0 0 9}$ & Min & -2.5 & -3.1 & -3.1 & 2 \\
\hline & Max & 7.0 & 5.5 & 5.6 & 1.8 \\
\hline & Obs. & 27 & 25 & 24 & -5.0 \\
\hline & & & & & 25.5 \\
\hline Total & Mean & 2.9 & 0.4 & 1.1 & 175 \\
\hline & Min & -18.0 & -7.3 & -6.4 & 25.0 \\
\hline
\end{tabular}

Years are those that we have data for the one year ahead GDP growth forecast error. 